\section{Pacific Northwest}

National Laboratory

Operated by Battelle for the

U.S. Department of Energy

\title{
T Tank Farm Interim Cover Test - Design Plan
}

\author{
Z.F. Zhang \\ J.M. Keller
}

July 2006

Prepared for the U.S. Department of Energy under Contract DE-AC05-76RL01830 


\section{DISCLAIMER}

This report was prepared as an account of work sponsored by an agency of the United States Government. Neither the United States Government nor any agency thereof, nor Battelle Memorial Institute, nor any of their employees, makes any warranty, express or implied, or assumes any legal liability or responsibility for the accuracy, completeness, or usefulness of any information, apparatus, product, or process disclosed, or represents that its use would not infringe privately owned rights. Reference herein to any specific commercial product, process, or service by trade name, trademark, manufacturer, or otherwise does not necessarily constitute or imply its endorsement, recommendation, or favoring by the United States Government or any agency thereof, or Battelle Memorial Institute. The views and opinions of authors expressed herein do not necessarily state or reflect those of the United States Government or any agency thereof.

PACIFIC NORTHWEST NATIONAL LABORATORY

operated by

BATTELLE

for the

UNITED STATES DEPARTMENT OF ENERGY

under Contract DE-AC05-76RL01830 
PNNL-15913 Rev. 0

\section{T Tank Farm Interim Cover Test - Design Plan}

Z.F. Zhang

J.M. Keller

July 2006

Prepared for the U.S. Department of Energy

under Contract DE-AC05-76RL01830 


\section{Summary}

The Hanford Site has 149 underground single-shell tanks that store hazardous radioactive waste. Many of these tanks and their associated infrastructure (e.g., pipelines, diversion boxes) have leaked. Some of the leaked waste has entered the groundwater. The largest known leak occurred from the T-106 Tank in 1973. Many of the contaminants from that leak still reside within the vadose zone beneath the T Tank Farm. CH2M Hill Hanford Group, Inc. seeks to minimize movement of this residual contaminant plume by placing an interim cover on the surface. Such a cover is expected to prevent infiltrating water from reaching the plume and moving it further. Pacific Northwest National Laboratory has prepared a design plan to monitor and determine the effectiveness of the interim cover. A three-dimensional numerical simulation of water movement beneath a cover was conducted to guide the design of the plan. Soil water content $(\theta)$, water pressure $(\psi)$, and temperature $(\mathrm{T})$ will be monitored using off-the-shelf equipment that can be installed by the hydraulic hammer technique. In fiscal year 2006, two instrument nests will be installed, one inside and one outside of the proposed cover. In fiscal year 2007, two additional instrument nests, both inside the proposed cover, will be installed. Each instrument nest contains a neutron access tube and a capacitance probe (to measure $\theta$ ), and four heat-dissipation units (to measure $\psi$ and $\mathrm{T}$ ). A datalogger and a meteorological station will be installed outside of the fence. Two drain gauges will be installed in locations inside and outside the cover for the purpose of measuring soil water flux. 


\section{Acronyms}

$\begin{array}{ll}\text { ARHCO } & \text { Atlantic-Richfield Hanford Company } \\ \text { ASTM } & \text { American Society for Testing and Materials } \\ \text { CCU } & \text { Cold Creek Unit } \\ \text { CHG } & \text { CH2M Hill Hanford Group, Inc. } \\ \text { CSI } & \text { Campbell Scientific, Inc. } \\ \text { DCT } & \text { Divergence Control Tube } \\ \text { DOE } & \text { Department of Energy } \\ \text { FY } & \text { Fiscal year } \\ \text { H } & \text { Hanford formation } \\ \text { HDU } & \text { Heat dissipation unit } \\ \text { HMS } & \text { Hanford Meteorological Station } \\ \text { IAEA } & \text { International Atomic Energy Agency } \\ \text { ID } & \text { Inside Diameter } \\ \text { MCNP } & \text { Monte Carlo Neutral Particles } \\ \text { OD } & \text { Outside Diameter } \\ \text { PMP } & \text { Project Management Plan } \\ \text { PNNL } & \text { Pacific Northwest National Laboratory } \\ \text { PVC } & \text { Polyvinyl chloride } \\ \text { QAP } & \text { Quality Assurance Plan } \\ \text { SST } & \text { Single-shell tank } \\ \text { STOMP } & \text { Subsurface Transport Over Multiple Phases } \\ \text { WIDS } & \text { Waste Information Data System } \\ \text { WMA } & \text { Waste Management Area } \\ & \end{array}$




\section{Table of Contents}

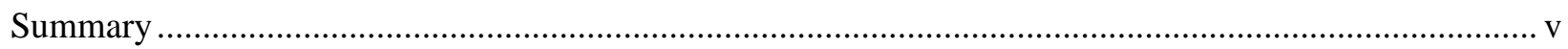

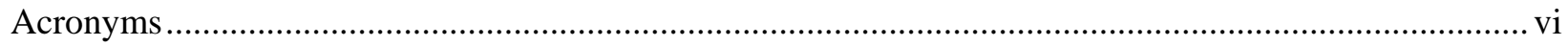

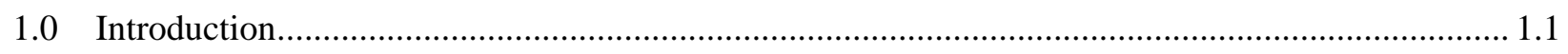

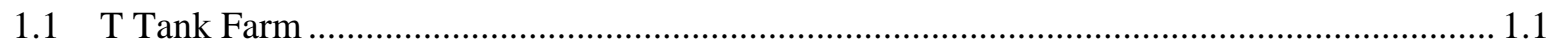

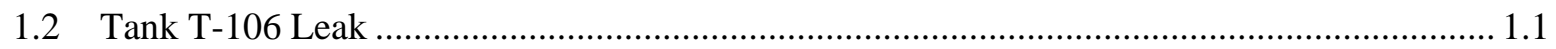

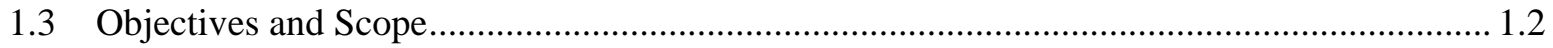

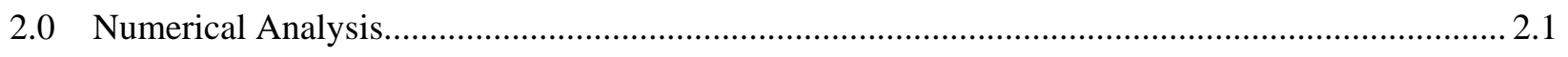

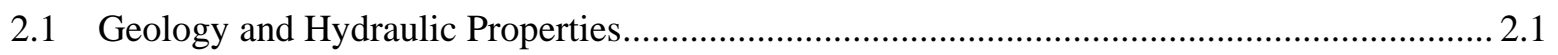

2.2 Simulation Domain, Initial and Boundary Conditions ..................................................... 2.1

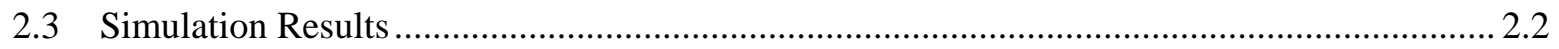

2.3.1 Time Series of Soil Water Content ........................................................................... 2.3

2.3.2 Time Series of Soil Water Pressure Head..................................................................... 2.3

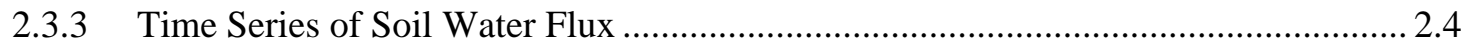

2.3.4 Spatial Distribution of Soil Water Saturation ............................................................. 2.5

3.0 Instrument Selection, Installation and Calibration................................................................... 3.1

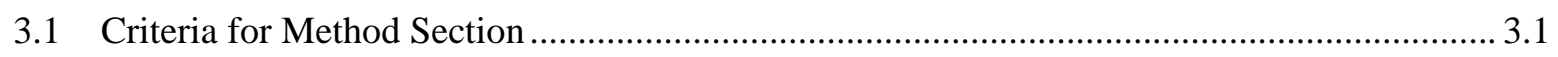

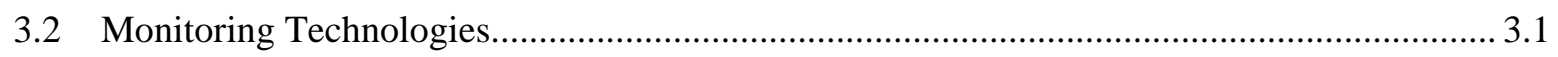

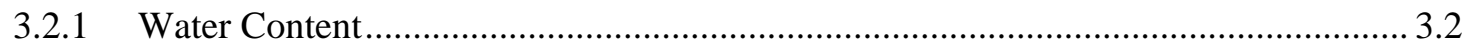

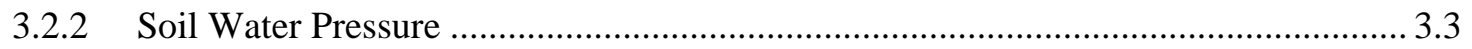

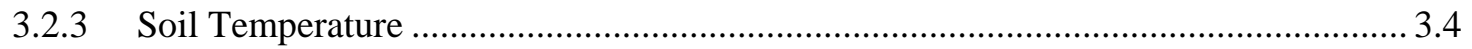

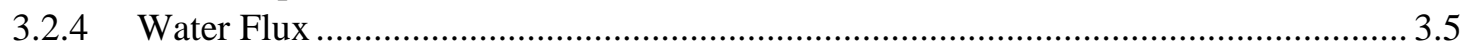

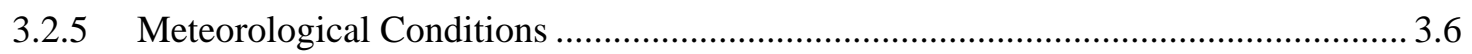

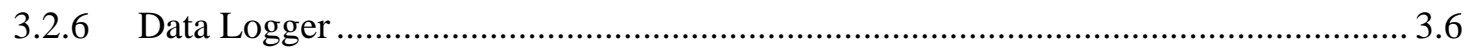

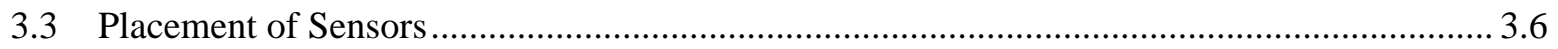

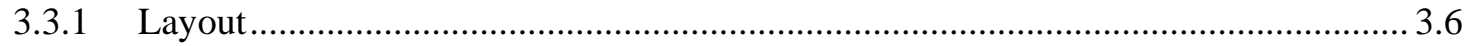

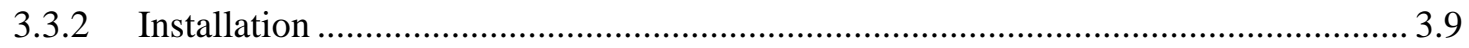

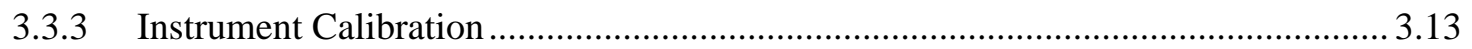

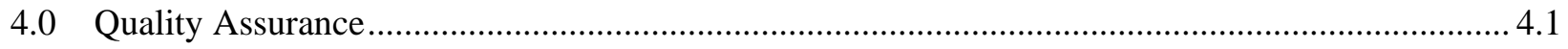

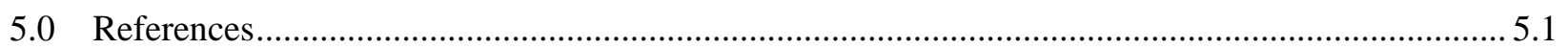

Appendix A: EnviroSMART Probe Installation Procedure................................................................. A.1 


\section{Figures}

1.1. Waste Management Area of the T Tank Farm and Surrounding Facilities ................................... 1.2

2.1. Simulation Domain Without and with an Interim Cover............................................................ 2.3

2.2. Time Series of Soil Water Content Inside and Outside the Interim Cover at Four Different

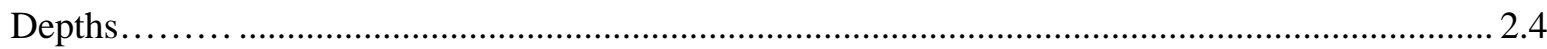

2.3. Soil Water Pressure Inside and Outside the Interim Cover at Four Different Depths ..................... 2.5

2.4. Soil Water Flux Inside and Outside the Interim Cover at Four Different Depths .......................... 2.6

2.5. Horizontal Distribution of Soil Water Saturation at Depth $0.5 \mathrm{~m}$ at Different Times ..................... 2.7

2.6. Horizontal Distribution of Soil Water Saturation at Depth $12.5 \mathrm{~m}$ in Different Times ................... 2.8

2.7. Vertical Distributions of Soil Water Saturation and Stream Lines at an Easting Transect Crossing the Center of Tanks T-104, T-105, and T-106........................................................... 2.9

2.8. Vertical Distributions of Soil Water Saturation and Stream Lines at an Easting Transect Crossing the Center Between Tank Row T-104, T-105, T-106 and Tank Row T-107, T-108

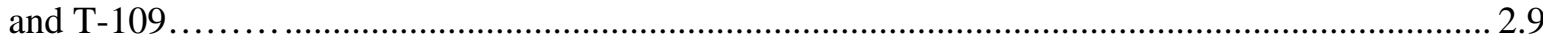

3.1. EnviroSMART Capacitance Probe for Measuring Moisture Content ............................................ 3.3

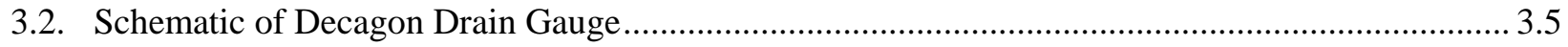

3.3. Plan View of $\mathrm{T}$ Tank Farm with the Monitoring Locations and Proposed Interim Cover ............... 3.7

3.4. Cutout of 3.3 Providing Close-up of Instrument Locations Relative to the Interim Cover

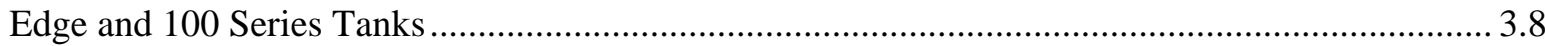

3.5. Relative Location of Each Drive within an Instrument Nest ....................................................... 3.10

3.6. HDU Installation and Packing Material Layering Scheme......................................................... 3.12 


\section{Tables}

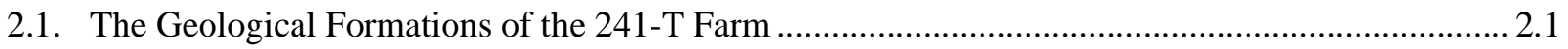

2.2. The Composite Hydraulic Parameters for Soils at Hanford's T Tank Farm................................... 2.2

3.1. Criteria For Selecting Alternative Vadose Zone Monitoring Methods............................................ 3.2

3.2. Selected Methods for Monitoring Soil Moisture Content and Decision Rationale .......................... 3.2

3.3. Selected Method for Measuring Soil Water Pressure and Decision Rationale ................................. 3.4

3.4. Selected Method for Measuring Soil Temperature and Decision Rationale.................................... 3.4

3.5. Selected Method to Monitor Soil Water Flux and Selection Rationale .......................................... 3.5

3.6. Selected Methods to Monitor Meteorological Conditions and Selection Rationale ......................... 3.6 


\subsection{Introduction}

The Hanford Site in southeastern Washington State has 149 underground single-shell tanks that store hazardous radioactive waste. Many of these tanks and their associated infrastructure (e.g., pipelines, diversion boxes) have leaked. Some of the leaked waste has entered the groundwater. The largest known leak occurred from the T-106 Tank in 1973. Many of the contaminants from that leak still reside within the vadose zone beneath the T Tank Farm. CH2M Hill Hanford Group, Inc. (CHG) seeks to minimize movement of this residual contaminant plume by placing an interim cover on the surface. Such a cover is expected to prevent infiltrating water from reaching the plume and moving it further. Pacific Northwest National Laboratory has prepared a test plan to monitor and determine the effectiveness of the interim cover.

\subsection{T Tank Farm}

According to Myers (2005), the T tank farm was built from 1943 to 1944. The T tank farm contains 12 single-shell tanks (SSTs) with $23 \mathrm{~m}$ (75 ft) diameter and 2,006,050 L (535,000 gal) capacity, four SSTs with $6.1 \mathrm{~m} \mathrm{(20} \mathrm{ft)} \mathrm{diameter} \mathrm{and} \mathrm{208,175} \mathrm{L} \mathrm{(55,000} \mathrm{gal)} \mathrm{capacity,} \mathrm{waste} \mathrm{transfer} \mathrm{lines,} \mathrm{leak} \mathrm{detection}$ systems, and tank ancillary equipment. The sediment cover from the apex of the tank domes to ground surface is $2.2 \mathrm{~m}(7.3 \mathrm{ft})$. All the tanks have a dish-shaped bottom. Figure 1.1 shows the waste management area (WMA) of the T tank farm and surrounding facilities.

In general, the vadose zone in the $\mathrm{T}$ tank farm consists of a portion of the thick, relatively coarse-grained sediments of the middle Ringold Formation $\left(\mathrm{R}_{\mathrm{wi}}\right)$, overlain by the finer grained sediments of the upper Ringold Formation $\left(\mathrm{R}_{\mathrm{tf}}\right)$ and the Plio-Pleistocene unit (also called the Cold Creek Unit, CCU), overlain by the coarser-grained sands and gravels of the Hanford formation $(\mathrm{H})$, which are exposed at the surface.

The upper $12 \mathrm{~m}$ of the Hanford formation was locally excavated and backfilled with gravelly sand during installation of the single-shell tanks.

\subsection{Tank T-106 Leak}

According to Hanford's Waste Information Data System (WIDS), an accidental leak from Tank T-106 occurred in 1973, and the details and chronology of the leak are well documented (ARHCO 1973; Routson et al. 1979). The leak was suspected to have started on April 20, 1973, during a routine filling operation. The leak stopped on June 10, 1973, when the free liquid contents of the tank were removed. The total duration of the leak was estimated to be 51 days. Approximately 435,000 liters (115,000 gallons) of fluid leaked from Tank T-106. The fluid contained cesium-137, strontium-90, plutonium, and various fission products, including technetium-99 $\left({ }^{99} \mathrm{Tc}\right)$. It is likely that the leak occurred in the southeast quadrant of the tank near the bottom of the tank side.

CHG has proposed to use an interim cover over Tank T-106 and the surrounding area in the T-tank farm to prevent or reduce infiltration of meteoric water entering into the subsurface in order to reduce the rate of the downward movement of leaked contaminants. 


\subsection{Objectives and Scope}

Objectives include documenting pre-cover conditions and changes in conditions beneath the cover as a function of distance from the edge of the cover and to a certain depth below the surface. A monitoring design plan is proposed in this report to examine and monitor the effectiveness of the interim cover. After a brief introduction of the background information in Chapter 1, Chapter 2 presents the results of numerical simulations that compare the changes of the soil water regime with and without an interim cover as guidance in making a monitoring plan. In Chapter 3, a description of monitoring equipment, equipment calibration, and installation procedures are presented. Chapter 4 provides a declaration about the quality assurance plan to verify the quality of the work and future monitoring. A subsequent monitoring plan will document data collection, analysis, reporting, and use.

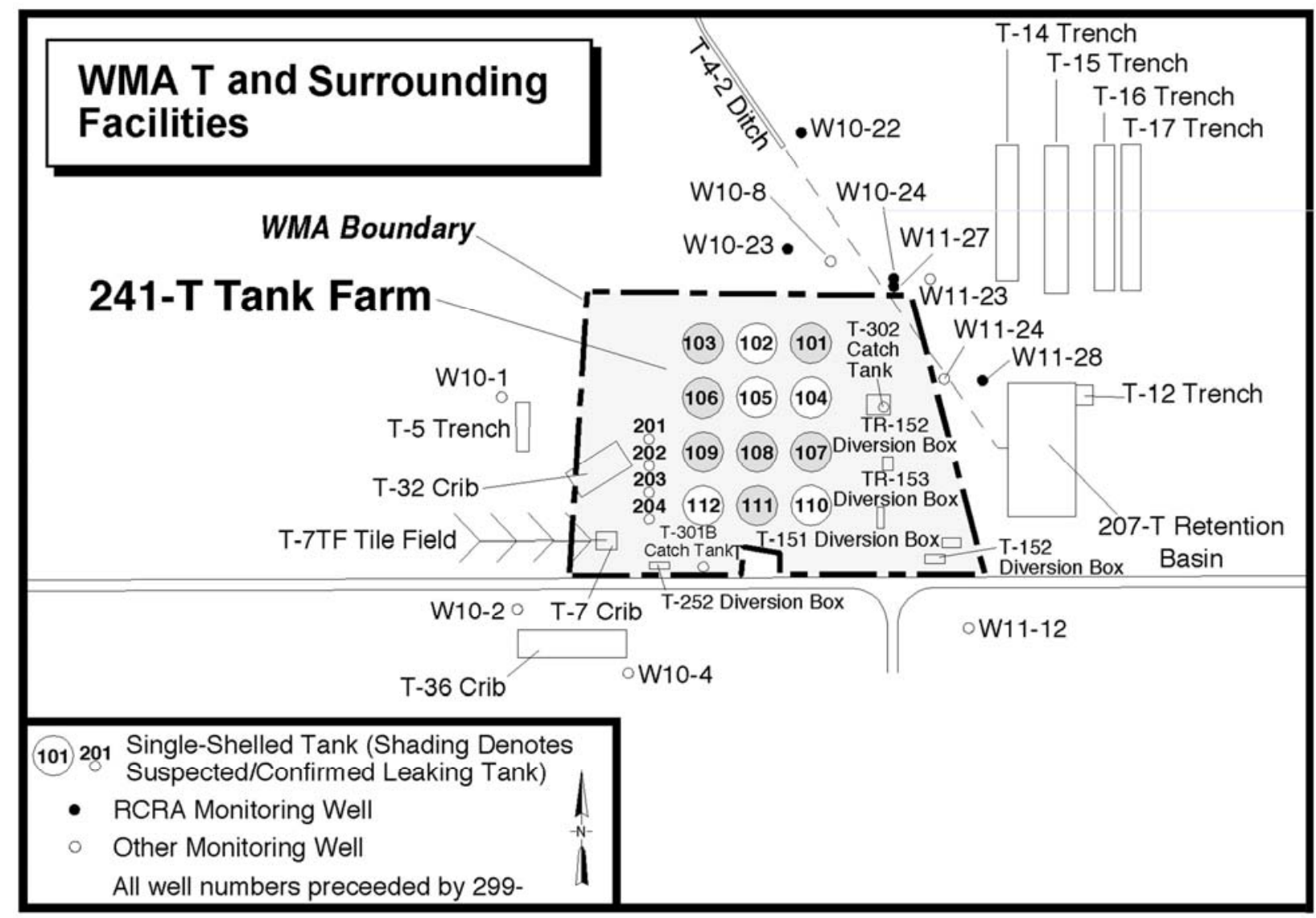

Figure 1.1. Waste Management Area of the T Tank Farm and Surrounding Facilities (from Myers 2005) 


\subsection{Numerical Analysis}

This section presents numerical simulation results of water flow after placing an interim cover over a portion of the T tank farm. The Subsurface Transport Over Multiple Phases (STOMP) numerical simulator (White and Oostrom 2004) was used to predict the movement of vadose zone water in response to placement of an interim cover on July 1, 2007.

The interim cover is expected to be a 1- to 2-cm-thick impermeable layer. The cover will be sloped so that excess water is drained to the edges where it will be collected and routed elsewhere. For this analysis, it is assumed that all excess water is successfully removed such that none infiltrates at the cover edge.

The simulation was conducted for 50 years after placing the interim cover. Water contents, pressure heads, and fluxes at specific locations were compared and contrasted to highlight changes caused by cover placement. The results were used to guide sensor selection and placement (explained more fully in Section 3.0). Some gas-phase and temperature effects may be caused by the interim cover, but these processes were considered secondary to the water-flow solution and were not simulated in this exercise. The following sections describe the geology and hydraulic properties, domain, initial and boundary conditions, and the simulation results.

\subsection{Geology and Hydraulic Properties}

The boreholes C4104 drilled near T-106 showed the geology as six main layers whose depths and soil types are given in Table 2.1 (Serne et al. 2004). The hydraulic parameters for each of the geological formations were from Khaleel et al. (2004) and are listed in Table 2.2.

\subsection{Simulation Domain, Initial and Boundary Conditions}

The three-dimensional physical domain was discretized with 74 nodes in both the east-west (x) and northsouth (y) directions and 55 nodes in the vertical (z) direction. Horizontal node spacing was uniformly $2 \mathrm{~m}$; vertical spacing was uniformly $1 \mathrm{~m}$. The total domain size was $148 \mathrm{~m}$ in the $\mathrm{x}$ and y directions and $55 \mathrm{~m}$ in the $\mathrm{z}$ direction. The origin of the simulation domain in the Hanford coordinate system was $\left(\mathrm{x}_{0}, \mathrm{y}_{0}\right)=(566710,136650) \mathrm{m}$. The domain includes the 12 large tanks $(\mathrm{T}-101$ through $\mathrm{T}-112)$ but not other infrastructures (e.g., the 200 series tanks and trenches). The nodes representing each tank were treated as inactive and did not interact with the changing water conditions in the vadose zone.

Table 2.1. The Geological Formations of the 241-T Farm

\begin{tabular}{||c|c|c|c||}
\hline Geology & Soil & Depth (m) & Depth (ft) \\
\hline 1. Backfill & Gravelly Sand & $0-12.2$ & $0-40$ \\
\hline 2. H1 Sand & Sand & $12.2-24.4$ & $40-80$ \\
\hline 3. H2 Sand & Silty Sand & $24.2-28.3$ & $80-93$ \\
\hline 4. Cold Creek Unit & Silty Sand & $28.3-32.9$ & $93-108$ \\
\hline 5. Upper Ringold Sand & Sand & $32.9-36.9$ & $108-121$ \\
\hline 6. Ringold Unit E & Sandy Gravel & $36.9-55.0$ & $121-180$ \\
\hline
\end{tabular}


Table 2.2. The Composite Hydraulic Parameters for Soils at Hanford's T Tank Farm (data from Khaleel et al. 2004)

\begin{tabular}{|c|c|c|c|}
\hline \hline Parameters & Sandy Gravel/ Gravelly Sand & Sand & Silty Sand \\
\hline$\theta_{\mathrm{s}}\left(\mathrm{m}^{3} \mathrm{~m}^{-3}\right)$ & 0.138 & 0.382 & 0.435 \\
\hline$\theta_{\mathrm{r}}\left(\mathrm{m}^{3} \mathrm{~m}^{-3}\right)$ & 0.010 & 0.044 & 0.067 \\
\hline$\alpha\left(\mathrm{m}^{-1}\right)$ & 0.021 & 0.012 & 0.0085 \\
\hline $\mathrm{n}(-)$ & 1.374 & 1.616 & 1.851 \\
\hline $\mathrm{K}_{\mathrm{s}}\left(\mathrm{m} \mathrm{s}^{-1}\right)$ & $5.600 \times 10^{-4}$ & $9.880 \times 10^{-5}$ & $2.400 \times 10^{-4}$ \\
\hline $\mathrm{L}(-)$ & 0.5 & 0.5 & 0.5 \\
\hline $\begin{array}{l}\theta_{\mathrm{s}}: \text { saturated water content; } \theta_{\mathrm{r}}: \text { residual water content; } \alpha: \text { van Genuchten } \\
(1980) \text { parameter related to soil capillarity; } \mathrm{n} \text { : a parameter related to }\end{array}$ \\
soil particle size distribution; $\mathrm{K}_{\mathrm{s}}$ : saturated hydraulic conductivity; and \\
L: the flow path connectivity-tortuosity coefficient. \\
\hline
\end{tabular}

The initial conditions within the simulation domain at an estimated time in which the interim cover was to be placed (July 1, 2007) were established using a two-step simulation. First, the uniform recharge rate was $3.5 \mathrm{~mm} / \mathrm{yr}$ (Khaleel et al. 2004) before 1945, the year the tanks were deployed. Then, the simulation ran from 1945 to July 1, 2007, the time the interim cover was to be installed, under the recharge rate of $100 \mathrm{~mm} / \mathrm{yr}$ (Khaleel et al. 2004). Normally, such hydraulic conditions would be the same as at similar depths across the domain, but, because of the shedding effect caused by the impermeable tanks, water flowing around the tanks (i.e., represented by inactive nodes) created slightly different initial conditions in the vicinity of the tanks.

At time zero (i.e., July 1, 2007), the interim cover was placed on the surface above Tanks T-105, -106, -108 , and -109 as shown in Figure 2.1. The cover was rectangular-shaped, and its size was 76×66 m [from $\left(\mathrm{x}_{1}, \mathrm{y}_{1}\right)=(36,36) \mathrm{m}$ to $\left(\mathrm{x}_{2}, \mathrm{y}_{2}\right)=(112,102) \mathrm{m}$ ] with the longer sides orienting to the east-west direction. The cover was simulated by changing the boundary condition inside the cover to zero flux and keeping the boundary condition at $100 \mathrm{~mm} / \mathrm{yr}$ outside the cover. A water table was applied to the bottom boundary to mimic the water table beneath the T tank farm.

The effects of the interim cover on soil water conditions were shown by comparing soil water variables at two locations, one inside the cover $[(\mathrm{x}, \mathrm{y})=(81,67) \mathrm{m}]$ and the other outside the cover

$[(\mathrm{x}, \mathrm{y})=(15,67) \mathrm{m}]$. As will be shown below, these effects are stronger at a shallower depth and weaker at a deeper depth.

\subsection{Simulation Results}

Although the simulations were carried out for 50 years after the placement of the interim cover, only the results for the first 3 years are presented because the monitoring plan is for a period of 3 years. The time series and/or the spatial distribution of the simulated results of soil water content, saturation, pressure head, and water flux are given below. 


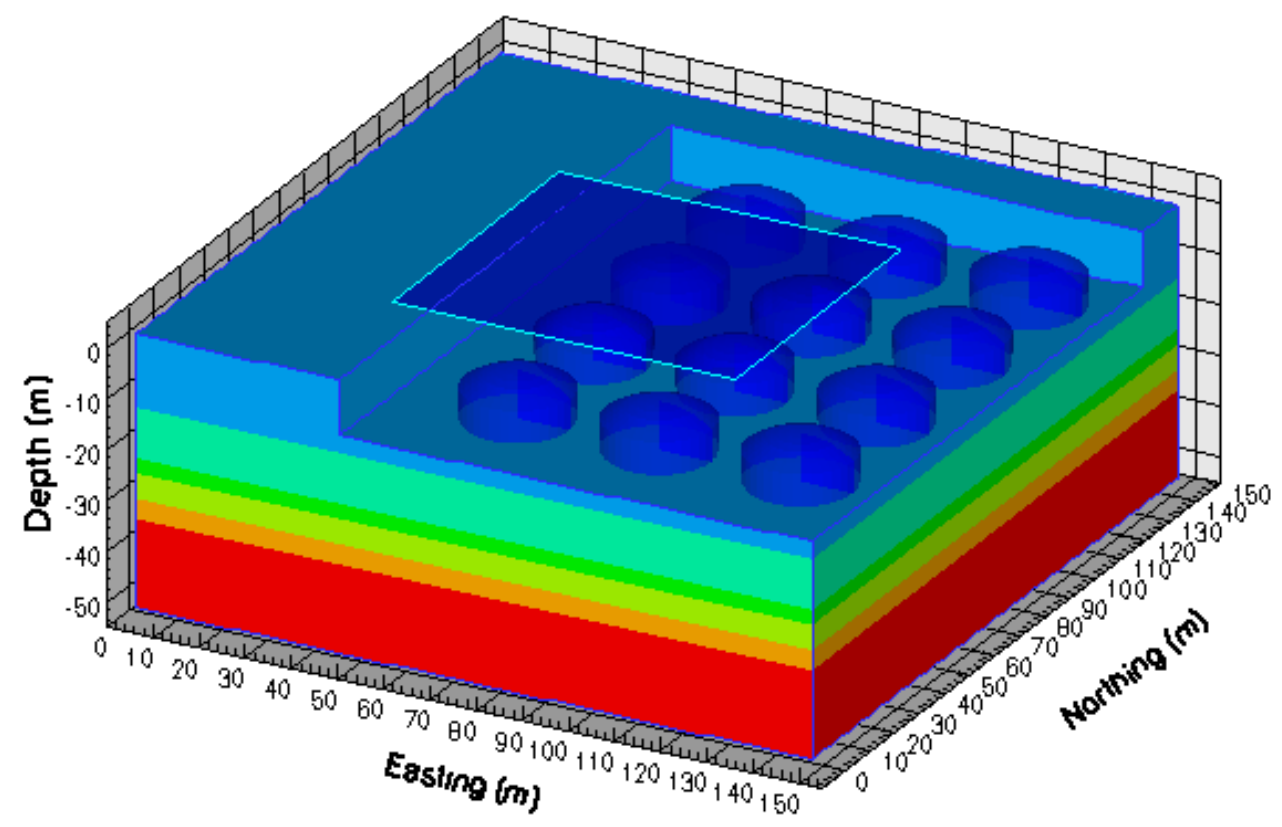

Figure 2.1. Simulation Domain Without and with an Interim Cover. The domain size was $(x, y, z)=(148,148,55) \mathrm{m}$. The origin of the simulation domain in the Hanford coordinate system was $\left(\mathrm{x}_{0}, \mathrm{y}_{0}\right)=(466710,136650) \mathrm{m}$.

\subsubsection{Time Series of Soil Water Content}

The time series of soil water content inside $[(x, y)=(81,67) m]$ and outside $[(x, y)=(15,67) m]$ the cover at four different depths are shown in Figure 2.2. As expected, the soil water content was stable through the simulation period outside the cover. Inside the cover, the soil water content decreased with time. The water-content decrease ranged from 0.0 at the $25.5-\mathrm{m}$ depth to $0.015 \mathrm{~m}^{3} \mathrm{~m}^{-3}$ at the $0.5-\mathrm{m}$ depth 1 year after the placement of the cover; 3 years after the placement of the cover, the water-content decrease ranged from $0.005 \mathrm{~m}^{3} \mathrm{~m}^{-3}$ at the $25.5-\mathrm{m}$ depth to $0.025 \mathrm{~m}^{3} \mathrm{~m}^{-3}$ at $15.5-\mathrm{m}$ depth. Note that, at the depths 15.5 and $25.5 \mathrm{~m}$, the slight difference in water content at the time the cover was placed (Year 2007.5) was caused by the shedding effects of the impermeable tanks.

\subsubsection{Time Series of Soil Water Pressure Head}

The time series of the soil pressure head inside $[(x, y)=(81,67) m]$ and outside $[(x, y)=(15,67) m]$ the interim cover at four different depths are shown in Figure 2.3. As expected, the soil water pressure was stable through the simulation period outside the cover. Inside the cover, the soil water pressure decreased (became more negative) with time. One year after the placement of the cover, the soil water pressure decrease ranged from 0.0 bar at $25.5-\mathrm{m}$ depth to 0.244 bar at $0.5-\mathrm{m}$ depth; 3 years after the placement of the cover, the soil water pressure decrease ranged from 0.018 bar at $25.5-\mathrm{m}$ depth to 0.407 bar at $0.5-\mathrm{m}$ depth. Note that, at depths of 15.5 and $25.5 \mathrm{~m}$, the slight difference in soil water pressure at the time the cover was placed (Year 2007.5) was caused by the shedding effects of the impermeable tanks. 

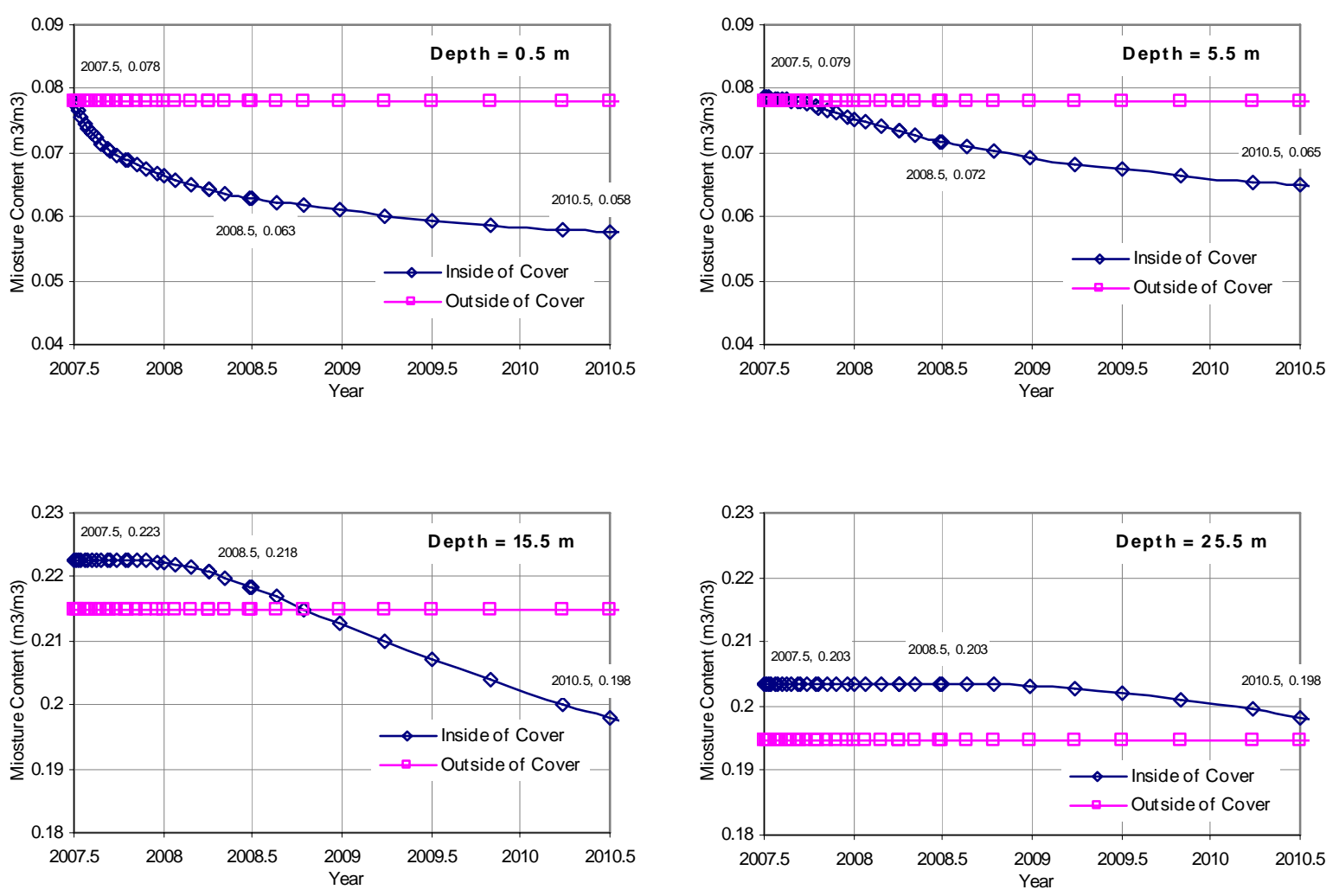

Figure 2.2. Time Series of Soil Water Content Inside $[(x, y)=(81,67) m]$ and Outside $[(\mathrm{x}, \mathrm{y})=(15,67) \mathrm{m}]$ the Interim Cover at Four Different Depths. The numbers by the curves are times and soil moisture contents at these times. The origin of the simulation domain in the Hanford coordinate system was $(\mathrm{x} 0, \mathrm{y} 0)=(466710,136650) \mathrm{m}$.

\subsubsection{Time Series of Soil Water Flux}

The time series of the fluxes inside $[(x, y)=(81,67) m]$ and outside $[(x, y)=(15,67) m]$ the interim cover at four different depths are shown in Figure 2.4. As expected, the soil water flux outside the cover was stable through the simulation period. Inside the cover, the soil water flux decreased with time. One year after the placement of the cover, the soil water flux decrease ranged from $0.2 \mathrm{~mm} / \mathrm{yr}$ at $25.5-\mathrm{m}$ depth to $94.7 \mathrm{~mm} / \mathrm{yr}$ at $0.5-\mathrm{m}$ depth; 3 years after the placement of the cover, the soil water flux decrease ranged from $27.2 \mathrm{~mm} / \mathrm{yr}$ at $25.5-\mathrm{m}$ depth to $98.3 \mathrm{~mm} / \mathrm{yr}$ at $0.5-\mathrm{m}$ depth. Note that, at depths of 15.5 and $25.5 \mathrm{~m}$, the slight difference in soil water flux at the time the cover was placed (Year 2007.5) was caused by the shedding effects of the impermeable tanks. 

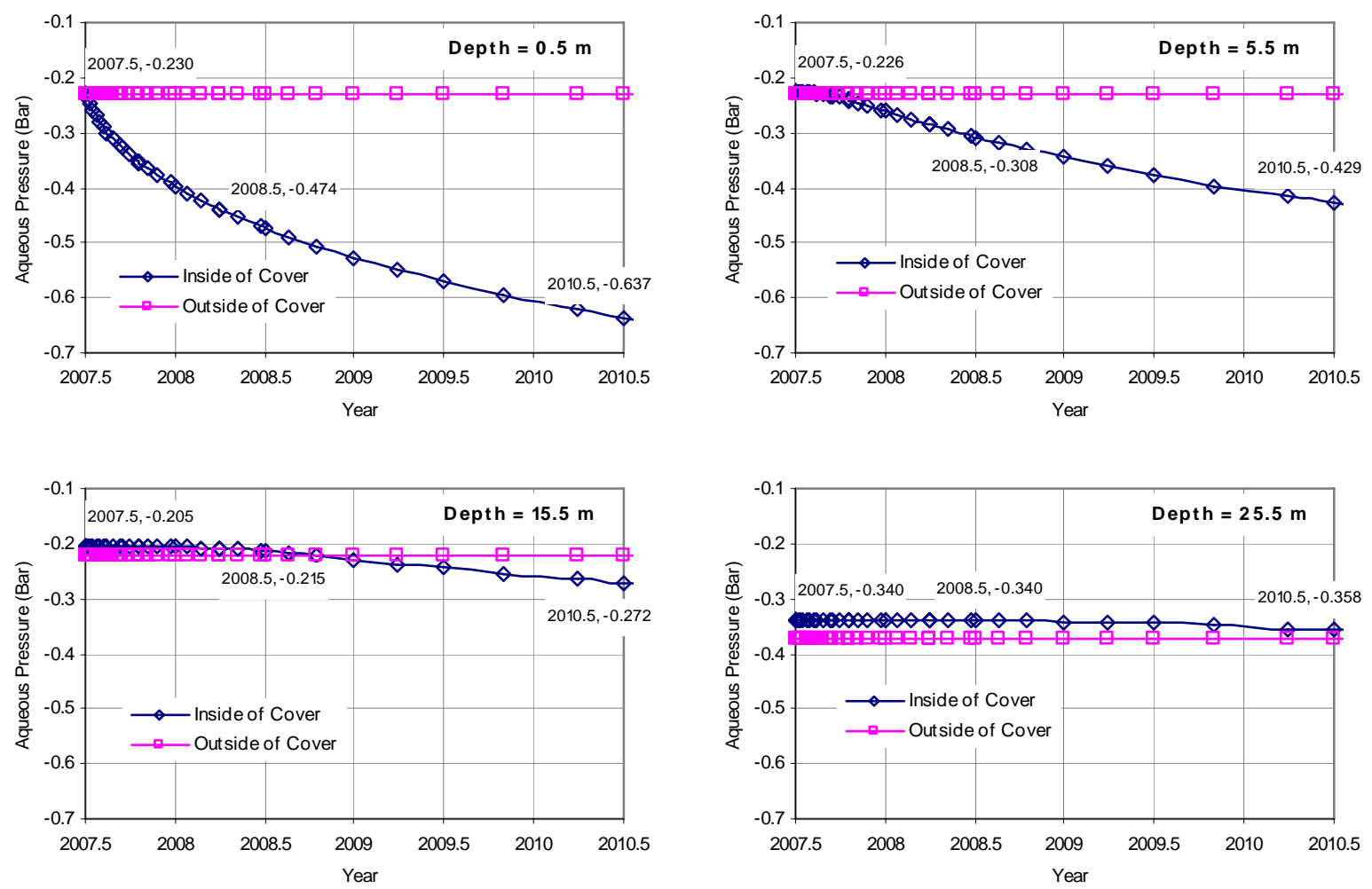

Figure 2.3. Soil Water Pressure Inside $[(x, y)=(81,67) m]$ and Outside $[(x, y)=(15,67) m]$ the Interim Cover at Four Different Depths. The numbers by the curves are times and soil water pressures at these times.

\subsubsection{Spatial Distribution of Soil Water Saturation}

The spatial distributions of soil water are shown using two-dimensional contours of soil water saturation in the selected horizontal planes and vertical planes at the time the cover was applied (Year 2007.5) and 1, 2 , and 3 years after the cover was applied.

Figure 2.5 shows the horizontal distribution of soil water saturation at a depth of $0.5 \mathrm{~m}$ in different times. At the time the cover was placed (Year 2007.5), the soil water was uniform, except that it was slightly wetter at the places right above each of the tanks because of the tank shedding effect. After the cover was emplaced, the soil beneath the cover became drier gradually. Similar effects can be seen at the depth of 15.5 m (Figure 2.6). 

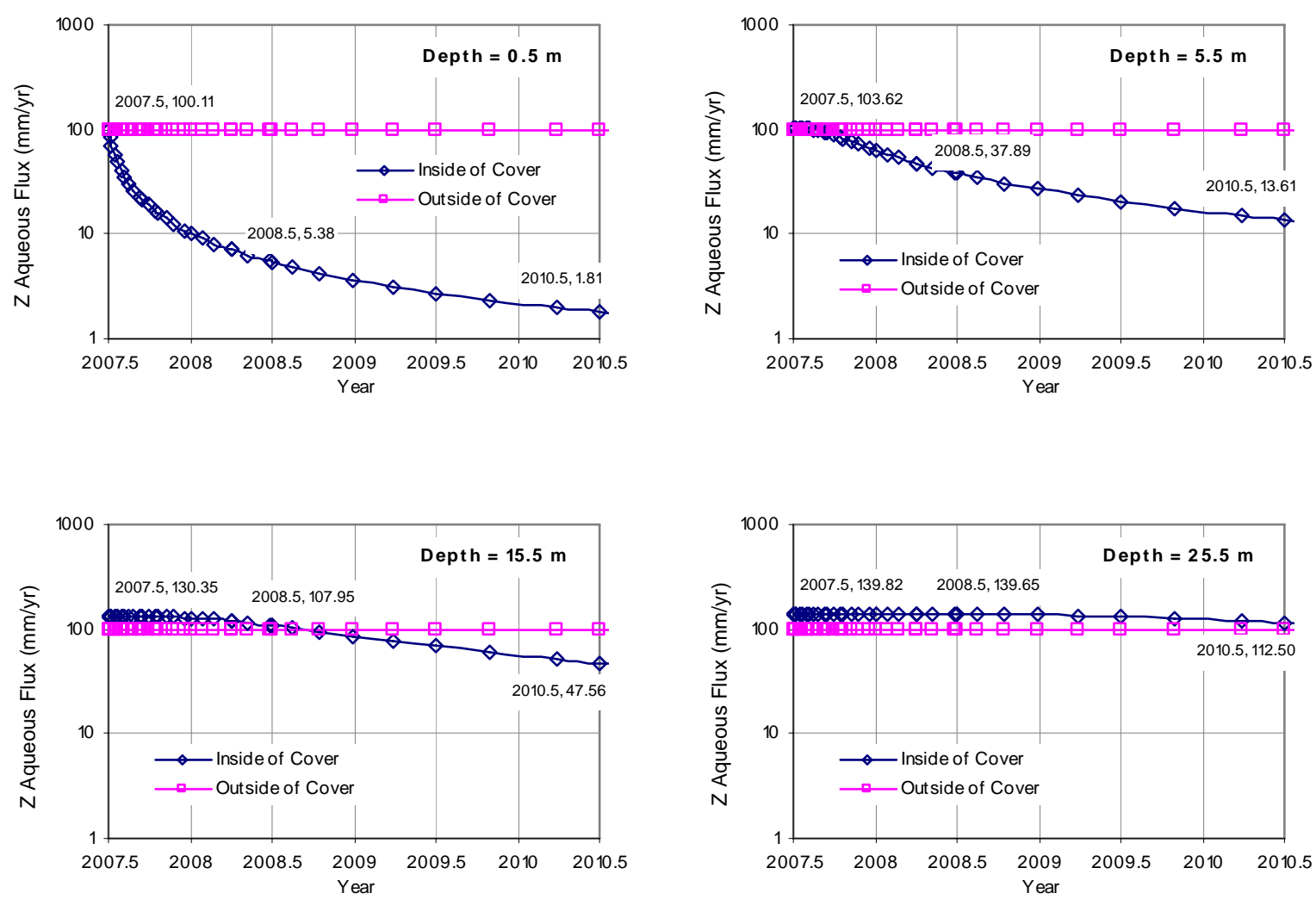

Figure 2.4. Soil Water Flux Inside $[(x, y)=(81,67) m]$ and Outside $[(x, y)=(15,67) m]$ the Interim Cover at Four Different Depths. The numbers by the curves are times and soil water fluxes at these times. 

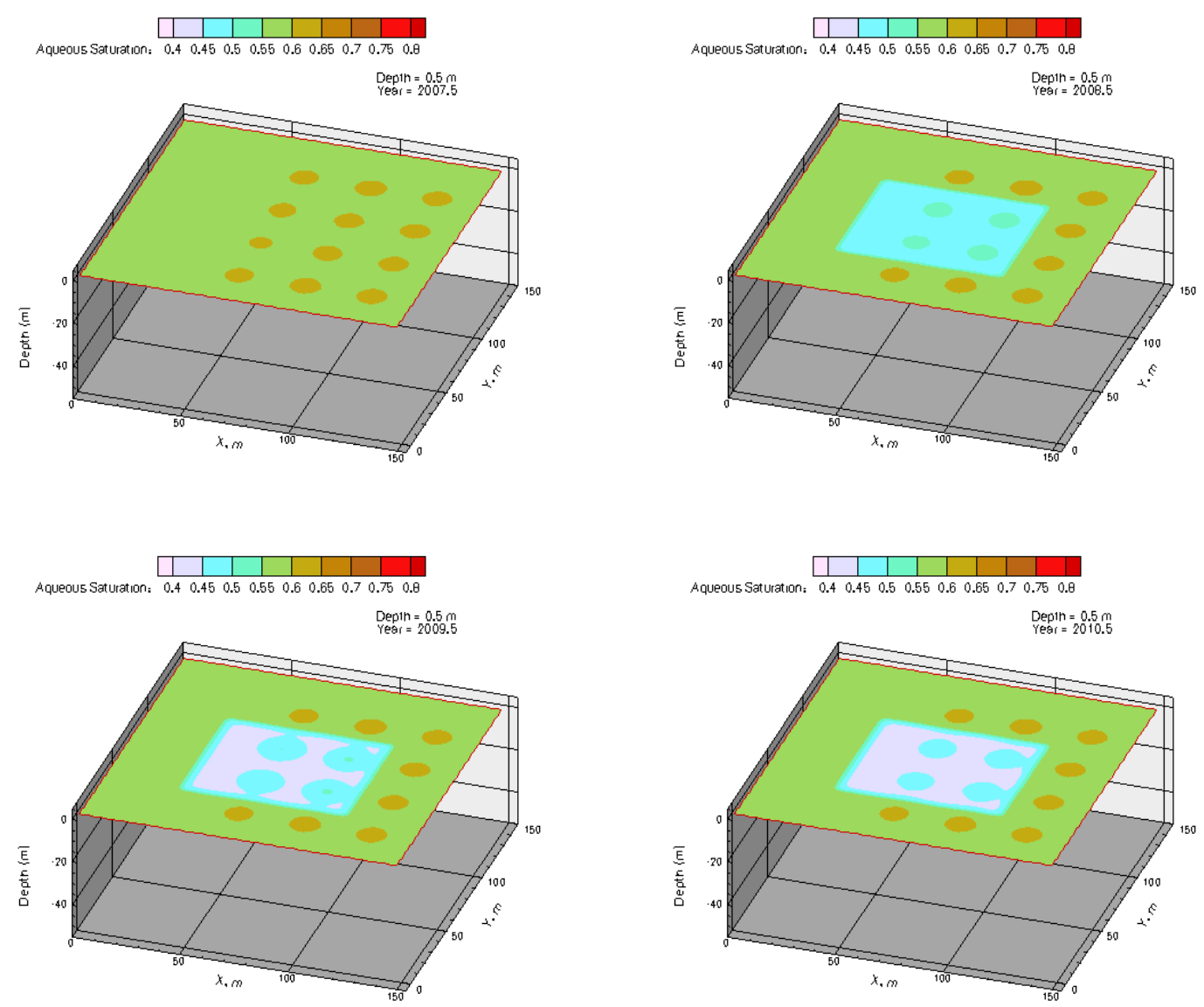

Figure 2.5. Horizontal Distribution of Soil Water Saturation at Depth $0.5 \mathrm{~m}$ at Different Times. The interim cover was emplaced in Year 2007.5.

Figure 2.7 shows the vertical distributions of soil water saturation and stream lines at an easting transect crossing the center of tanks T-104, T-105, and T-106. The soil beneath the cover became drier gradually. The stream lines indicate that, as the soil beneath the cover became drier, some water at the relatively wetter region beneath the place without a cover moved laterally into the drier region beneath the covered region. This effect became stronger with time. This lateral movement of water is referred as the "edging effect." The results suggest that, 3 years after the placement of the cover, the distance being affected beyond the edge of the cover in the easting direction was about $5 \mathrm{~m}$. Figure 2.8 shows vertical distributions of soil water saturation and stream lines at an easting transect crossing the center between tank row T-104, T-105, T-106 and tank row T-107, T-108, and T-109. Similar results were observed in Figure 2.8 as those in Figure 2.7. 

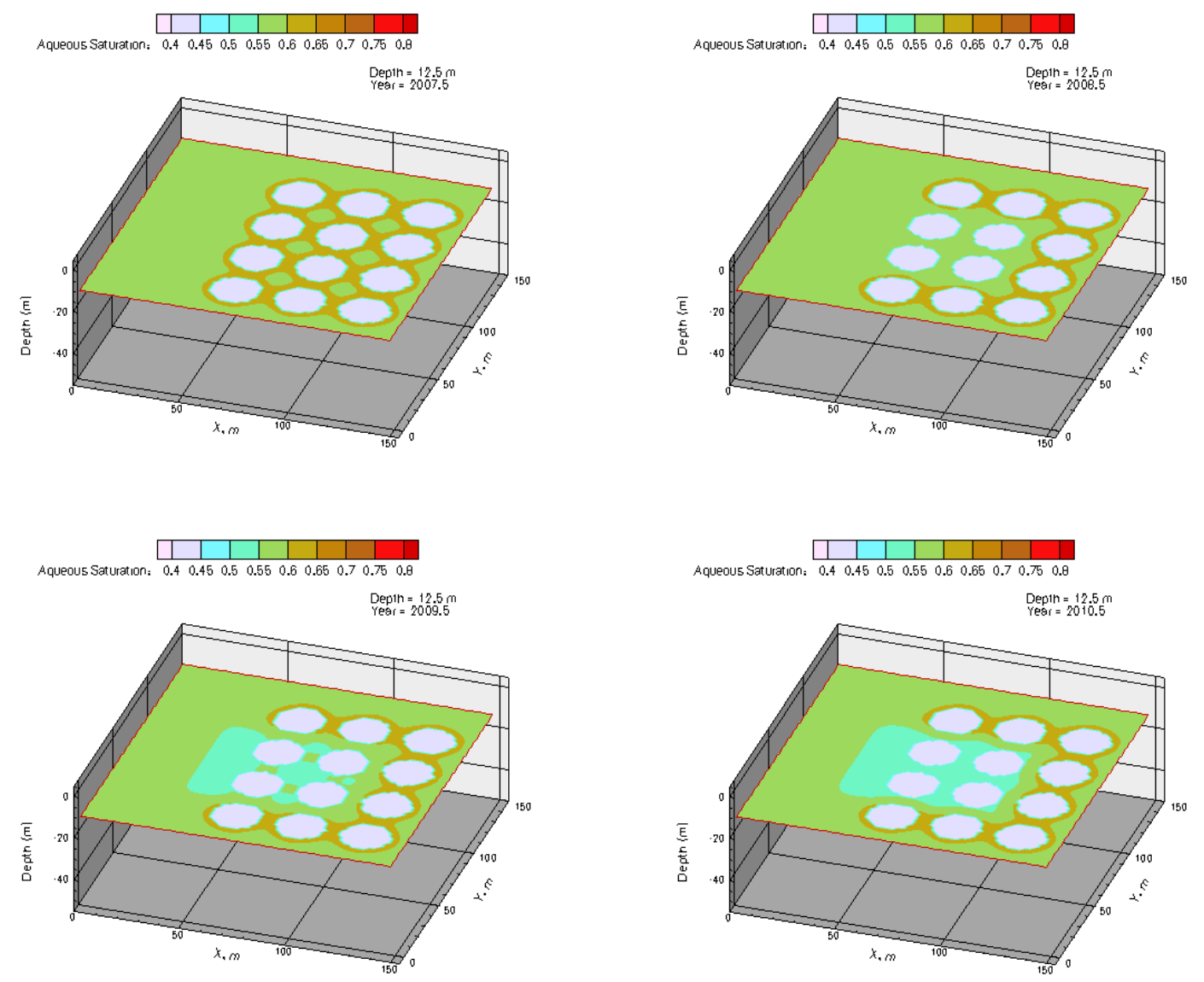

Figure 2.6. Horizontal Distribution of Soil Water Saturation at Depth $12.5 \mathrm{~m}$ in Different Times. The interim cover was emplaced in Year 2007.5. 

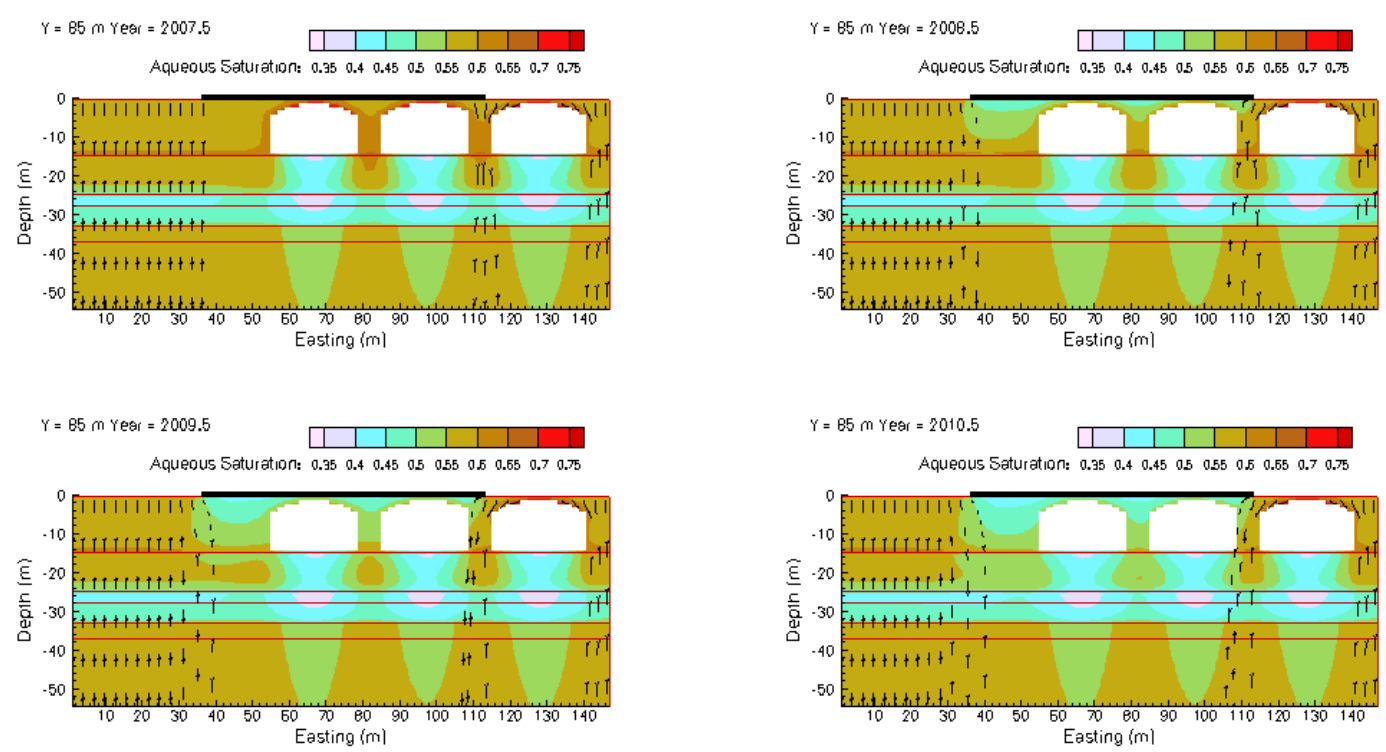

Figure 2.7. Vertical Distributions of Soil Water Saturation and Stream Lines at an Easting Transect Crossing the Center of Tanks T-104, T-105, and T-106. The interim cover was emplaced in Year 2007.5.
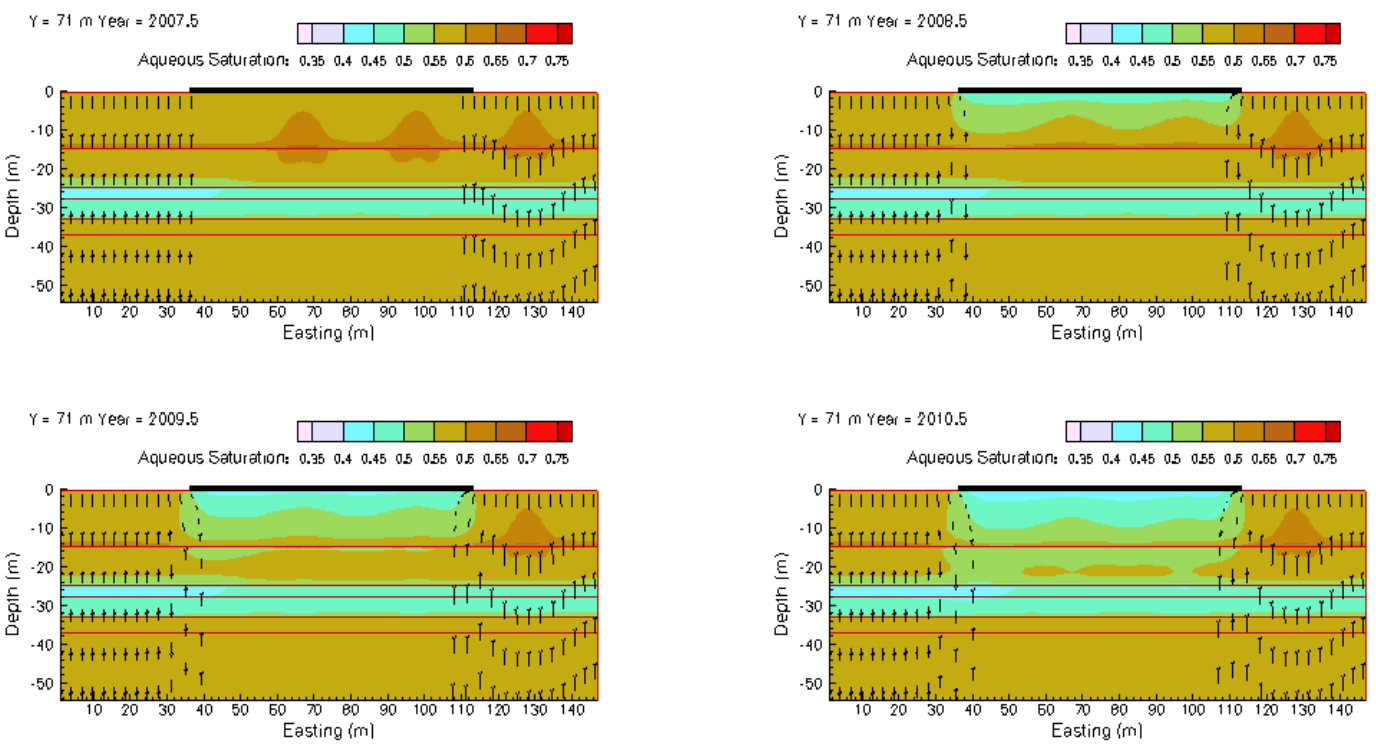

Figure 2.8. Vertical Distributions of Soil Water Saturation and Stream Lines at an Easting Transect Crossing the Center Between Tank Row T-104, T-105, T-106 and Tank Row T-107, T-108 and T-109. The interim cover was emplaced in Year 2007.5. 
2.10 


\subsection{Instrument Selection, Installation and Calibration}

A monitoring design plan is presented to meet the 3-year objectives of documenting interim cover performance by measuring pre-cover subsurface conditions and changes in subsurface conditions beneath the cover as a function of distance from the edge of the cover and the depth below surface. Results from simulations containing the proposed interim cover were used in developing the plan. Simulations suggest that with the installation of an interim cover, over the anticipated 3-year monitoring period, observable changes in moisture content and soil water pressure will be restricted to an approximate depth of $15.5 \mathrm{~m}$. Predicted changes in moisture content 3 years after cover installation range from $0.005 \mathrm{~m}^{3} \mathrm{~m}^{-3}$ at the 25.5-m depth to $0.025 \mathrm{~m}^{3} \mathrm{~m}^{-3}$ at the $15.5-\mathrm{m}$ depth. At the $0.5-\mathrm{m}$ depth, the predicted change in moisture content is $0.020 \mathrm{~m}^{3} \mathrm{~m}^{-3}$. Soil water pressure changes over the same 3-year period range from a decrease of $0.018 \mathrm{bar}$ at a depth of $25.5 \mathrm{~m}$ to a decrease of 0.407 bar at $0.5 \mathrm{~m}$. Meanwhile, drainage fluxes at the $0.5-\mathrm{m}$ depth decreased by $98.3 \mathrm{~mm} / \mathrm{yr}$ at the $0.5-\mathrm{m}$ depth. Three years after cover installation, edge effects, or lateral movement of water from wetter to drier regions, were observed at a lateral distance of approximately $5 \mathrm{~m}$ from the cover edge. These summarized simulation results were used to guide sensor selection and placement.

This section describes the criteria used to select the various measurement methods and the details of the design plan for testing the effectiveness of the interim cover, including selected measurement methods, monitoring locations, and performance requirements.

\subsection{Criteria for Method Section}

Table 3.1 illustrates criteria for selecting monitoring methods that were modified from criteria described by Everett et al. (1984). The criteria provide for a systematic way of determining which monitoring technologies will best serve the given objectives. Because of restrictions of working within the $\mathrm{T}$ tank farm, considerable attention was given to potential installation problems and constraints when selecting methods. In addition, methods were chosen that will use a hydraulic hammer to install instruments at depth. While the selected technologies may not meet all criteria, they do encompass the majority of criteria presented.

\subsection{Monitoring Technologies}

Variables to be monitored are chosen based on their contribution to describing soil water flux conditions and inputs. Variables to be monitored are 1) soil water content, 2) soil water pressure, 3) soil temperature, 4) soil water flux, and 5) meteorological conditions, including precipitation and air temperature. This section identifies the methods chosen to monitor the identified variables and the basis for their selection. 
Table 3.1. Criteria For Selecting Alternative Vadose Zone Monitoring Methods

\begin{tabular}{|r|l|}
\hline Item & \multicolumn{1}{|c|}{ Criteria } \\
\hline 1 & Applicability to field usage \\
\hline 2 & Measurement resolution \\
\hline 3 & Measurement range \\
\hline 4 & Representative volume \\
\hline 5 & Limitations \\
\hline 6 & Cost \\
\hline 7 & Potential installation problem \\
\hline 8 & Reliability and life expectancy \\
\hline 9 & Effects of surrounding environment \\
\hline 10 & Data collection system and wire length effects \\
\hline 11 & Continuous or discrete sampling \\
\hline 12 & Maintenance requirements \\
\hline 13 & Effect of hazardous waste on measurement \\
\hline 14 & Power requirements \\
\hline 15 & Multiple use capabilities \\
\hline 16 & Other concerns \\
\hline
\end{tabular}

\subsubsection{Water Content}

Moisture content as a function of depth will be measured to monitor the performance of the interim cover in reducing water flux from baseline conditions. Soil water measurements will be used to track wetting fronts and produce estimates of water fluxes using available soil water potential data and soil hydraulic properties. Two methods, neutron moisture probe and capacitance probe, will be employed to monitor soil moisture. This affords the benefit of providing certain data through redundancy, while at the same time offering advantages presented by each method. Additionally, both methods of measurement provide the accuracy (Table 3.2) needed to capture the predicted changes in soil moisture content after the interim cover is in place.

Table 3.2. Selected Methods for Monitoring Soil Moisture Content and Decision Rationale

\begin{tabular}{|c|c|c|l||}
\hline $\begin{array}{c}\text { Selected Monitoring } \\
\text { Method(s) }\end{array}$ & Manufacturer & Accuracy & \multicolumn{1}{c||}{ Rationale } \\
\hline $\begin{array}{c}\text { Neutron probe } \\
\text { (503 DR }\end{array}$ & $\begin{array}{c}\text { CPN International, } \\
\text { Inc. }\end{array}$ & $\begin{array}{c} \pm 0.016 \\
\mathrm{~cm}^{3} \mathrm{~cm}^{-3(a)}\end{array}$ & $\begin{array}{l}\text { Reliable and standard method. Installation } \\
\text { requirements limited to access tubes. Meets } \\
\text { measurement accuracy and resolution requirements. }\end{array}$ \\
\hline $\begin{array}{l}\text { Capacitance probe } \\
\text { (EnviroSMART) }\end{array}$ & $\begin{array}{c}\text { Sentek (Distributed } \\
\text { by Campbell } \\
\text { Scientific) }\end{array}$ & $\begin{array}{c} \pm 0.01 \\
\mathrm{~cm}^{3} \mathrm{~cm}^{-3(\mathrm{~b})}\end{array}$ & $\begin{array}{l}\text { Capable of continuous automated measurements. } \\
\text { Easily implemented in tank farm. Meets measurement } \\
\text { accuracy and resolution requirements. }\end{array}$ \\
\hline $\begin{array}{l}\text { (a) D. Carter, CPN International, Inc., personal communication, May 24, 2006. } \\
\text { (b) Campbell Scientific, Inc. (CSI 2006b). }\end{array}$ \\
\hline
\end{tabular}


The neutron moisture probe method has a proven history as a standard and reliable method for monitoring soil moisture content (Evett 2001). It has the added benefit of minimal installation requirements, namely, easy installation of an access tube and depth of measurement primarily only restricted by access tube depth. The key limitation to the neutron moisture probe is that it requires operation by a trained individual, meaning that entry into the tank farm is required to perform the measurements. Based on $\mathrm{T}$ tank farm entry restrictions, this limits neutron probe measurements to once every 3 months.

The capacitance probe is a profile-type capacitance probe that provides continuous automated measurements of soil moisture content. This provides the capability for analyzing moisture content changes over small time intervals and monitoring water input pulses that occur after intense rain events. Capacitance probe installation constraints limit measurements to depths much shallower than neutron probes. Furthermore, the neutron probe measurement volume is larger than the capacitance probe measurement volume. Given the expected soil moisture contents to be encountered, the radius of measurement using the neutron probe will range from 30 to $40 \mathrm{~cm}$ while the capacitance probe is limited to a $10-\mathrm{cm}$ radius.

The neutron moisture probe to be used is the 503DR hydroprobe manufactured by CPN International, Inc. (Martinez, CA). The 503DR hydroprobe has a history of successful use at Hanford and is currently used for a number of Hanford waste site soil moisture monitoring programs (DOE 2005; Ward et al. 2000). CHG will provide, maintain, and operate the neutron moisture probe.

The capacitance probe to be used is a profile type probe distributed by Campbell Scientific, Inc. (CSI) (Logan, UT) called an EnviroSMART probe (CSI 2006a, b). Figure 3.1 presents a picture of the probe and key parts. The standard probe configuration allows for a measurement depth of $2 \mathrm{~m}$. The EnviroSMART probe sensors and electronics are independently housed within a $5.65 \mathrm{~cm}$ (2.22 inch) polyvinyl chloride (PVC) access tube. Such a setup aids in installation and allows for access to the sensors were one to fail. Both the 503DR hydroprobe and the EnviroSMART probe require calibrations to relate probe measurements to moisture content.

Table 3.2 lists the manufacturer's documented instrument accuracy along with summarizing the rationale for using the chosen or equivalent monitoring method.

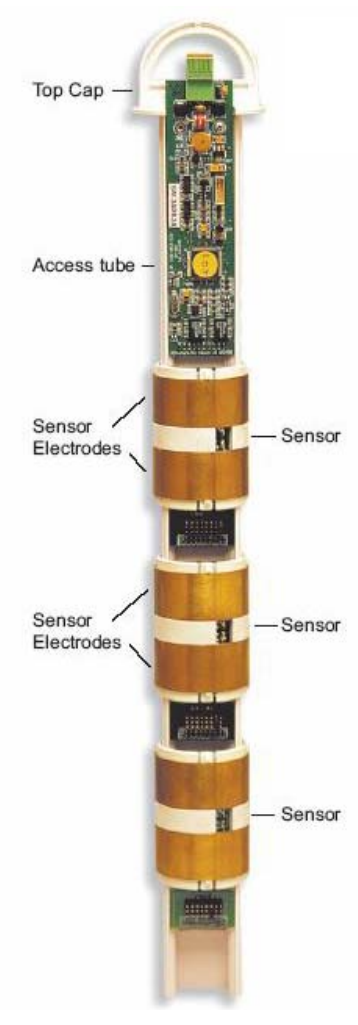

Figure 3.1. EnviroSMART Capacitance Probe for Measuring Moisture Content (from CSI 2006b)

\subsubsection{Soil Water Pressure}

Soil water pressure will be measured at select depths to monitor the performance of the interim cover in reducing water flux from baseline conditions. Soil water pressure measurements will be used to track wetting or drying fronts, identify pressure gradients, and produce estimates of water fluxes using available soil water-content data and soil hydraulic properties. 
Heat dissipation unit (HDU) probes (CSI 2006c) will be installed to achieve automated monitoring of soil water pressure. HDUs are chosen in part because of their capability to measure soil water pressure in the range predicted by simulations to exist in sediments underlying the T tank farm (i.e. -0.2 to -0.6 bar). In addition, HDUs provide affordable measurements of soil water pressure and also the added benefit of measuring soil temperature. The size of a single HDU is also a benefit, with the CSI HDU (model 299) dimensions being $1.5 \mathrm{~cm}$ in diameter and $60 \mathrm{~mm}$ in length. HDUs do not measure soil water pressure directly, but require a calibration to convert measurements to an equivalent soil water pressure. Table 3.3 gives the accuracy of HDUs and summarizes the rationale for their use.

Table 3.3. Selected Method for Measuring Soil Water Pressure and Decision Rationale

\begin{tabular}{||c|c|c|l||}
\hline $\begin{array}{c}\text { Selected Monitoring } \\
\text { Method(s) }\end{array}$ & Manufacturer & Accuracy & \multicolumn{1}{c||}{ Rationale } \\
\hline Heat dissipation units & CSI & $\pm 20 \%{ }^{(a)}$ & $\begin{array}{l}\text { Inexpensive alternative method. Capable of } \\
\text { continuous automated measurements. Also } \\
\text { measures soil temperature. }\end{array}$ \\
\hline \multicolumn{2}{|l|}{ (a) Calibration dependent. Accuracy value taken from Reece et al. (1996). } \\
\hline
\end{tabular}

\subsubsection{Soil Temperature}

The soil temperature will be measured and recorded during set time intervals at various locations. Measuring soil temperature provides information on soil temperature gradients that contribute to liquid water and vapor movement in the subsurface. Automated soil temperature measurements will be made using HDUs, which provide measurements of both soil temperature and soil water pressure. HDUs provide for an efficient method to measure soil temperature, given that they will already be used for measuring soil water pressure. Table 3.4 gives the operational accuracy for the measurement method along with summarizing the rationale for using the chosen monitoring method.

Table 3.4. Selected Method for Measuring Soil Temperature and Decision Rationale

\begin{tabular}{|c|c|c|l||}
\hline $\begin{array}{c}\text { Selected Monitoring } \\
\text { Method(s) }\end{array}$ & Manufacturer & Accuracy & \multicolumn{1}{c||}{ Rationale } \\
\hline Heat dissipation units & CSI & $\pm 0.25^{\circ} \mathrm{C}^{(\mathrm{a})}$ & $\begin{array}{l}\text { Continuous automated } \\
\text { measurements. Also measures soil } \\
\text { water pressure. }\end{array}$ \\
\hline \multicolumn{2}{|l|}{ (a) J. Ritter, CSI, personal communication, June 2, 2006 } \\
\hline
\end{tabular}




\subsubsection{Water Flux}

The water flux will be continuously measured and recorded at two locations. One location will document drainage under the condition without a cover at the T tank farm while the second location will be beneath the interim cover. The water flux will be measured using a wick lysimeter drain gauge manufactured by Decagon (Pullman, WA) (Decagon 2003). The Decagon drain gauge (Figure 3.2) offers an automated method to directly measure soil water flux. The drain gauge also offers the benefit of relatively little soil displacement during installation compared to other direct measurement methods. The units provide sufficient accuracy and resolution given the predicted drainage of the simulation outside of the interim cover.

Dimensions of the Decagon drain gauge include an 8-inch OD, 2.2-foot-long divergence control tube (DCT), on top of a 2.5-inch-OD, 2.7-foot-long tube housing the wick, dosing siphon, and gauge.

Table 3.5 gives the manufacturer's documented instrument accuracy and resolution along with summarizing the rationale for using the chosen monitoring method.

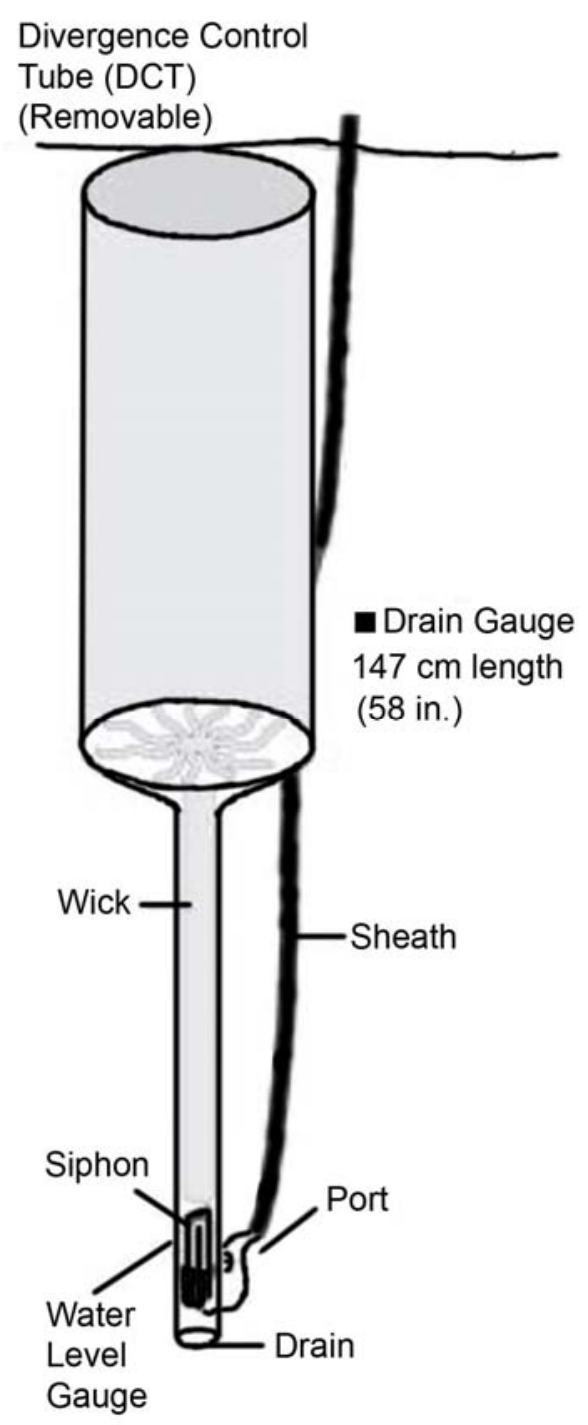

Figure 3.2. Schematic of Decagon Drain Gauge (from Decagon 2003)

Table 3.5. Selected Method to Monitor Soil Water Flux and Selection Rationale

\begin{tabular}{|lcccc||}
\hline $\begin{array}{c}\text { Selected } \\
\text { Monitoring } \\
\text { Method(s) }\end{array}$ & Manufacturer & Accuracy & Resolution & \multicolumn{1}{c||}{ Rationale } \\
Drain Gauge & Decagon & $\pm 10 \%{ }^{(\text {a) }}$ & $1 \mathrm{ml}^{(\text {a) }}$ & $\begin{array}{l}\text { Direct measurement of water flux. } \\
\text { Capable of continuous automated } \\
\text { measurements. Requires minimal } \\
\text { soil displacement relative to other } \\
\text { direct methods. }\end{array}$ \\
(a) D. Cobos, Decagon, personal communication, May 24, 2006
\end{tabular}




\subsubsection{Meteorological Conditions}

Precipitation and air temperature will be continuously monitored using a single meteorological station. Monitoring precipitation directly at $\mathrm{T}$ tank farm is critical given the importance of precipitation as an input into the water balance model. Localized thunderstorms that occasionally occur at Hanford produce spatially variable short term, high energy precipitation events. Such events require that a meteorological monitoring station be located at the $\mathrm{T}$ farm to document potential localized precipitation events.

Power requirements necessary for a heated rain gauge necessitated that the rain gauge not be heated. As such, the rain gauge will not accurately measure precipitation because of snowfall. Given the proximity of the Hanford Meteorological Station (HMS) and the uniformity of snowfall across the Hanford Site, it is acceptable to conclude that snowfall measured by the HMS will accurately describe the snowfall at the $\mathrm{T}$ farm. Table 3.6 gives the manufacturer's documented instrument accuracy along with summarizing the rationale for using the chosen monitoring method.

Table 3.6. Selected Methods to Monitor Meteorological Conditions and Selection Rationale

\begin{tabular}{|c|c|c|c||}
\hline $\begin{array}{c}\text { Selected Monitoring } \\
\text { Method(s) }\end{array}$ & Manufacturer & Accuracy & \multicolumn{1}{||}{ Rationale } \\
\hline Rain gauge & $\begin{array}{c}\text { Texas Electronics } \\
\text { (distributed by CSI) }\end{array}$ & $\pm 1 \%{ }^{(\mathrm{a})}$ & $\begin{array}{l}\text { Standard methods. Capable of } \\
\text { continuous automated measurements. }\end{array}$ \\
\hline Thermometer & CSI & $\pm 0.1^{\circ} \mathrm{C}^{(\mathrm{b})}$ & \\
\cline { 1 - 2 } $\begin{array}{l}\text { (a) (CSI 2002). } \\
\text { (b) (CSI 2006c). }\end{array}$ & & \\
\hline
\end{tabular}

\subsubsection{Data Logger}

The measurement and control device to be used to operate the tensiometer pressure transducers, HDUs, capacitance probes, drain gauge, and meteorological station is the CR10X manufactured by CSI (Logan, UT). The CR10X allows the data to be measured, processed, stored, and retrieved. However, permanent power does not exist near the proposed placement of the data logger. This requires that the data logger and peripherals be powered by a battery that can be recharged with a solar panel.

\subsection{Placement of Sensors}

This section describes the instrument layout design, designating the spatial distribution of instruments and access tubes within the T tank farm and the datalogger and meteorological station outside the $\mathrm{T}$ tank farm fenceline. Additionally, the method of installation is described for the access tubes and each instrument type.

\subsubsection{Layout}

The instrument layout is designed to monitor vadose zone conditions with depth both under the future interim cover and outside of the cover for purposes of identifying cover effectiveness. Instrument placement takes into account the need for both short term results (less than 3 years) and the potential for continued monitoring and collection of data past the initial 3-year commitment. Simulations suggest that 
the significant changes in subsurface conditions 3 years after cover placement will primarily be contained to the top $5.5 \mathrm{~m}$ of sediment. Longer time periods are required before significant changes propagate to deeper depths. As such, a combination of shallow and deep instrument placement is incorporated into the monitoring design.

The design groups instruments and access tubes into nests, with each nest being composed of a vertical access tube for neutron moisture probe measurements, an EnviroSMART capacitance probe, and HDU units at four depths. Figure 3.3 and Figure 3.4 provide a plan view of the instrument locations and the prospective western and northern extent of the interim cover. Four instrument nests (one outside of the cover and three inside the cover) are to be placed in a north/south direction covering both the interim cover and the uncovered area. This placement design allows the measurement of cover effectiveness in reducing drainage as well as investigating cover edge effects. The instrument nests will lie within backfill material, except that the lower part of the neutron access tubes will extend to the Hanford formation.

Nests A and D will be installed in fiscal year (FY) 2006 and will provide baseline conditions before installing the cover in the summer of 2007. Nest A and D will be installed at a separation distance of approximately $30 \mathrm{~m}$, with nest $\mathrm{A}$ being outside the cover area and nest $\mathrm{D}$ being inside the future cover area (Figure 3.4). Nests B and C will be installed in FY 2007 before placing the cover. Nests B and C will be inside the cover area, with Nest $\mathrm{B}$ being at the edge of the cover. The exact spacing of Nests $\mathrm{B}$ and $\mathrm{C}$ will be decided once the design of the interim cover is completed. The distance between the instrument nests and the 100 series tanks will be between 10 to $15 \mathrm{~m}$. The final distance will ultimately

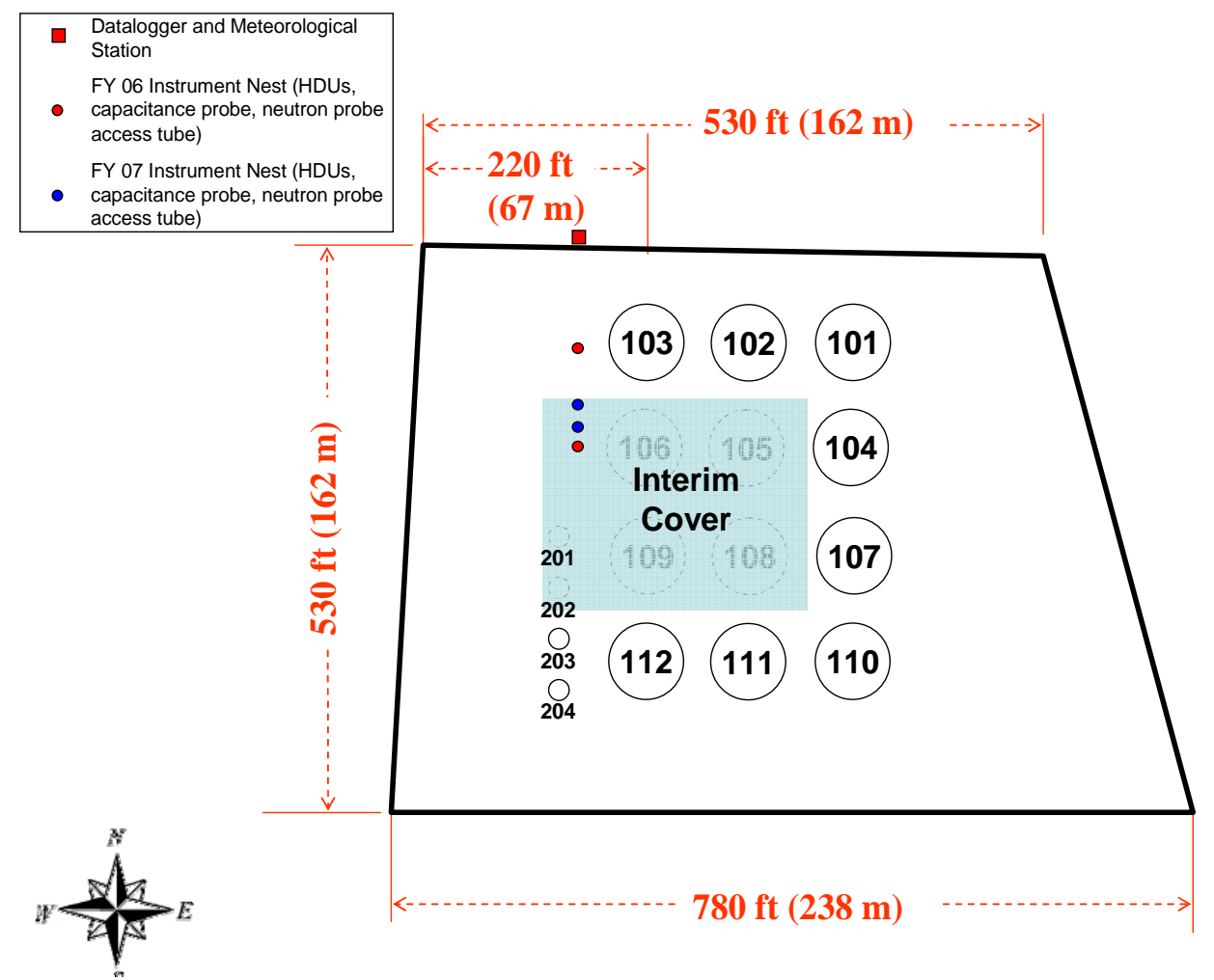

Figure 3.3. Plan View of $\mathrm{T}$ Tank Farm with the Monitoring Locations and Proposed Interim Cover 

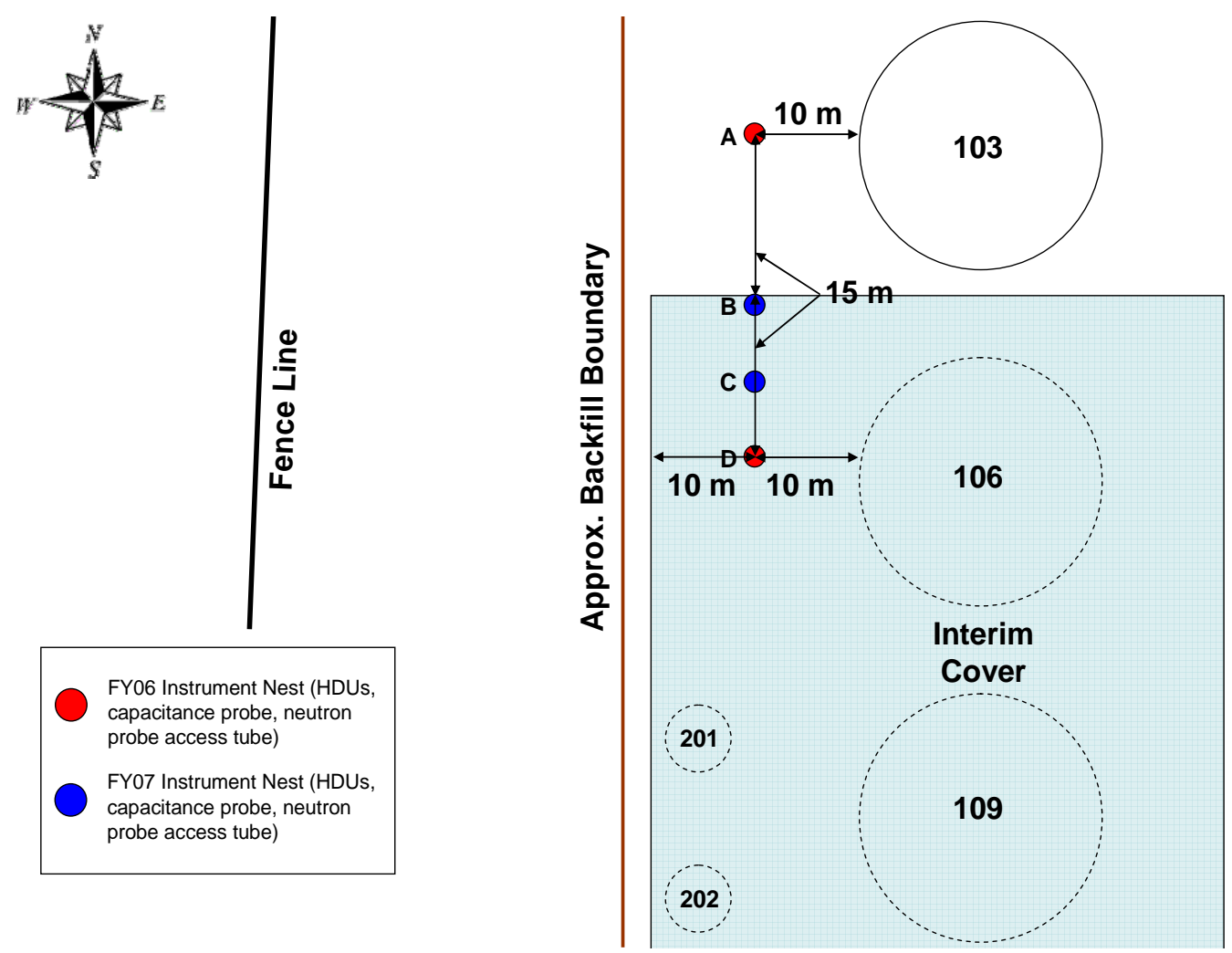

Figure 3.4. Cutout of Figure 3.3 Providing Close-up of Instrument Locations Relative to the Interim Cover Edge and 100 Series Tanks. The distance between the instrument nests and the 100 series tank may ultimately be larger than $10 \mathrm{~m}$, depending on location of a known electrical trench.

depend on the exact location of an electrical trench in the vicinity of the nests. After cover placement, Nest A will provide subsurface conditions outside the cover area. Nest D will provide measurement of subsurface condition under the cover at a location that is minimally influenced by cover edge and tank boundary conditions. Nest B, at the edge of the cover, will provide subsurface measurements that are aimed to explore the magnitude of cover edge effects. If the lateral extent of cover edge effects is large enough to influence measurements at Nest $\mathrm{C}$, this nest will provide additional information on the extent and magnitude of edge effects. If measurable edge effects do not extend to Nest $\mathrm{C}$, this nest will serve as a redundant measurement of conditions similar to Nest D. Based on the performance of Nests A and D during the first year of operation, additional nests (other than B and C) may be installed in FY 2007 as a plan of recovery if instruments at Nests A and D fail.

The design plan calls the interim cover to be extended to a distance west and north of Tank T-106 to provide for sufficient cover area for subsurface monitoring. Such a large extension is needed for two reasons: 1) instrument nests need to be placed a sufficient distance from the tanks to prevent the measurement of elevated moisture contents and soil water pressures caused by the shedding effects tanks have on soil water movement and 2) simulations suggest that edge effects or the lateral movement of soil water to drier soil underneath the cover are limited to no more than $5 \mathrm{~m}$ from the edge of the cover 3 years after installing the cover. While we propose to measure edge effects, we also aim to measure conditions below the interim cover not experiencing edge effects. This requires the placement of at least one nest at 
a sufficient distance from the cover edge to refrain from measuring edge effects. Given the results of the simulations and the simulation uncertainties involved, the placement of instrument nests at a distance of $10 \mathrm{~m}$ (32.8 ft) from the edge of the cover is sufficient to avoid measuring edge effects.

The neutron probe access tube to be placed at each nest is to be installed to a depth of approximately $15 \mathrm{~m}$ (49.2 ft). This depth placement will allow for monitoring of moisture content changes within both backfill material and the Hanford formation underlying the tank farm backfill material.

EnviroSMART capacitance sensors at each nest will be installed from approximately 1 foot below the surface to the end of the $2 \mathrm{~m}(6.6 \mathrm{ft})$ length of the probes. Sensors will be located at five depths: 60, 90, 130, 180, and $230 \mathrm{~cm}$.

Four HDU sensors will be placed at each nest at depths of 1, 2, 5, and $10 \mathrm{~m}$.

Two drain gauges will be placed near the soil surface, one outside the cover at Nest A and a second beneath the cover at Nest $\mathrm{D}$ (Figure 3.4). Under unvegetated conditions, as exist in $\mathrm{T}$ tank farm, the nearsurface soil texture largely controls drainage conditions (Gee et al. 2005). For relevancy of drainage data, it is essential that both drain gauges be placed within the tank farm, incorporating the near surface soil texture of the tank farm. To reduce excavation requirements, the drain gauge will be installed such that the top of the unit is near the tank farm surface.

The alteration of subsurface conditions immediately surrounding the boreholes and instrument measurement volumes bring about the need to provide sufficient distance between instruments at each nest. A separation distance no less than $80 \mathrm{~cm}$ is deemed ample for this purpose. This number was derived by calculating the measurement radius of the neutron moisture probe (IAEA 1970) at the simulated lowest moisture content $\left(0.056 \mathrm{~m}^{3} \mathrm{~m}^{-3}\right)$, corresponding to when the neutron probe measurement radius would be greatest. The neutron probe measurement radius was chosen because its measurement volume is larger than that of the other instruments being installed. This calculation provides an approximate measurement radius of $40 \mathrm{~cm}$. Given uncertainties in the calculation and to accommodate differing instrument diameters, two times the neutron probe measurement radius is used as the instrument separation distance. For the drain gauges at Nests A and D, a minimum 80-cm distance between the drain gauges and the nearest instrument will suffice. Figure 3.5 provides the layout of instruments at each nest.

The weather station and datalogger will be placed immediately outside the fenceline of the $\mathrm{T}$ tank farm, directly north of the instrument nests. Placing both the datalogger and weather station outside the tank farm allows for easy access to both units for maintenance and troubleshooting.

\subsubsection{Installation}

A hydraulic hammer will be used to pound a cone-tipped hollow drive shaft into the soil to create an open borehole in which to place the instruments. The benefit of using the hydraulic hammer to create a borehole as opposed to drilling is that the hydraulic hammer technique avoids bringing potentially contaminated soil to the surface. The cone tip on the drive shaft has the capability to be removed once the desired driving depth is reached. This allows instruments to be placed down the borehole through the inside of the drive shaft as the drive shaft is removed from the soil. Likewise, the drive shaft can remain in the soil as a permanent access tube. The diameter of the borehole can be increased or decreased using differing drive shaft and drive head diameters. Cost constraints, material strength considerations, and 
characteristics of the subsurface material limit the size of the shaft and head that can be used. The typical drive shaft size has an inside diameter (ID) of 1.75 inches and an outside diameter (OD) of 2.5 inches and will be used to place instruments in this monitoring project. The hydraulic hammer has the capability to drive rods into the ground at an angle, but for this monitoring scheme, all placement will be vertical.

In addition to the instrument to be installed using a hydraulic hammer, all nests will be accompanied by T posts to prevent foot and vehicle traffic over the instruments and signage disclosing that subsurface monitoring is in progress and identifying a contact person.

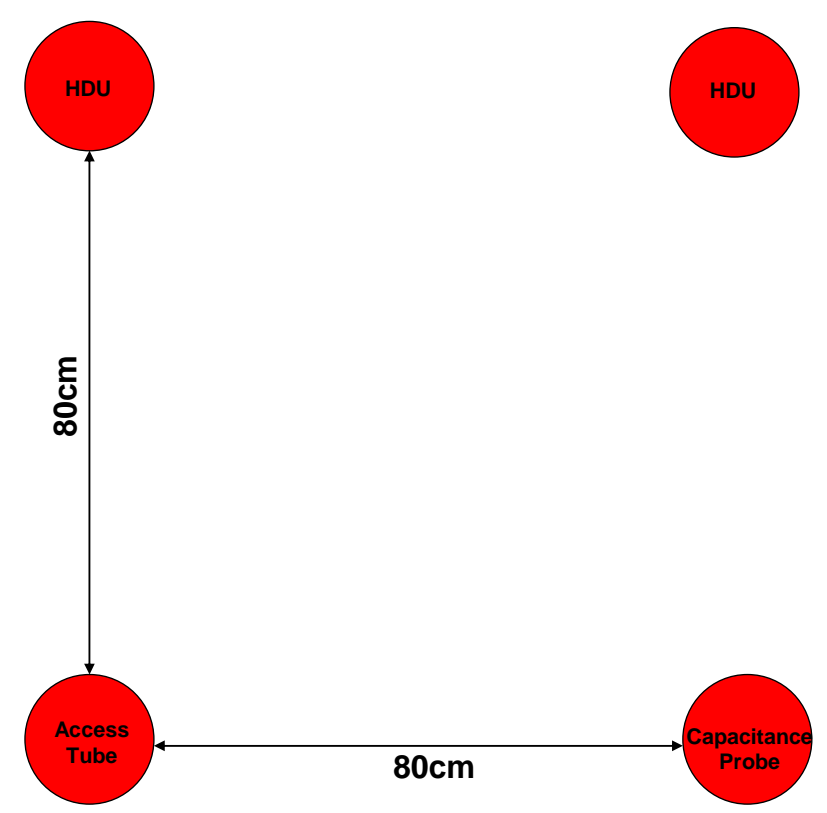

Figure 3.5. Relative Location of Each Drive within an Instrument Nest

\section{Neutron Moisture Probe Access Tubes}

The neutron probe access tubes will be installed using the basic function of the hydraulic hammer. A 1.75 inch ID (2.5 inch OD) steel access tube will be driven vertically by the hydraulic hammer to a depth

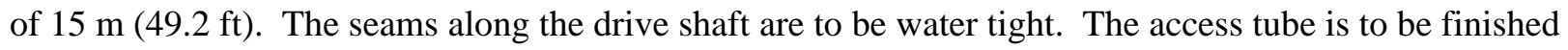
flush with the tank farm surface using a small casing and cap to protect the access tube from vehicle traffic and to prevent water from draining into the access tube.

\section{EnviroSMART Capacitance Probe}

This installation will require that the standard drive rod and drive head be modified. A drive rod with an ID larger than the 2.22 inch OD EnviroSMART PVC access tube will be driven vertically to a depth of approximately $3.4 \mathrm{~m}$. Once the target depth is reached, the drive cone is detached from the shaft, and the cone is isolated from the capacitance probe by surrounding it with 20/40 clean sand until the borehole depth is approximately $2.9 \mathrm{~m}$. The EnviroSMART PVC access tube is placed at depth through the drive rod, with the top of the probe being approximately $30 \mathrm{~cm}(1 \mathrm{ft})$ below ground surface. As the drive rod is extracted, a 20/40 clean sand is packed in the annulus surrounding the PVC access tube so that air gaps do not exist between the access tube and the soil. Accurate soil moisture content measurements with the 
EnviroSMART probe requires good contact between the soil and access tube. In other words, there must be minimal airspace between the soil and access tube. When selecting the size of the drive rod, consideration should be given to creating sufficient open space between the PVC tube and drive rod to allow proper packing of the 20/40 sand, yet keeping the thickness of the open space to a minimum so the measured moisture content is not heavily skewed by the packing material. A small layer of bentonite is to be used at the top of the PVC access tube to fill the annulus to reduce the potential for preferential flow through the 20/40 sand pack material.

After the PVC access tube and packing material is emplaced, follow installation instructions in the Instruction Manual (CSI 2006a) to install the sensor string (see Appendix A for details):

1. Seal the bottom of the access tube with a bung provided by the manufacturer.

2. Place desiccant within the access tube.

3. Remove soil and dust that has accumulated within the access tube.

4. Install the sensors within the access tube and emplace the cape and seal it with a water-tight and weather-resistant sealant.

The remaining $30 \mathrm{~cm}$ of borehole will consist of casing and soil material from the surface of the tank farm. The casing and soil will protect the probe from surface traffic. In addition, the casing will allow for easy excavation of the soil if the probe sensors and electronics need to be accessed.

\section{Heat Dissipation Units}

Four HDUs per nest will be placed in one of two ways. The first possible placement involves two drives, each drive allowing for the placement of two HDUs. The drives will be divided into "deep" drives for the placement of HDUs at 10-m and 5-m depths and "shallow" drives for the placement of HDUs at 1-m and 2-m depths. Using two drives makes sure that there is enough space within the drive rod to place the instruments, run the wiring, and properly emplace the packing material, but this may increase installation time because two boreholes are being driven. The second possible placement scheme places all four HDUs in a single borehole. This placement is preferred but may not be possible because of the reduction in available open borehole space for placing packing material because of additional wiring within the borehole. Which placement is used will ultimately be decided in the field. Figure 3.6 provides a representation of the packing material and instrument layering scheme for installing two HDUs per borehole. The procedures of HDU installation are described below.

1. For each drive, the drive shaft will be driven approximately $0.6 \mathrm{~m}$ past the maximum placement depth.

2. The drive cone is disconnected from the drive shaft, and as the rod is removed, 20/40 clean sand is added to bring the level to $10 \mathrm{~cm}$ below the bottom instrument depth.

3. The HDU and a silica flour suspension are added for a total $20-\mathrm{cm}$ thickness of silica flour. Silica flour is packed around the HDU to supply optimum contact between the sensor and surrounding soil material.

4. $20 \mathrm{~cm}$ of sand is packed on top of the silica flour, and bentonite is added to the borehole to $30 \mathrm{~cm}$ before placing the next HDU. Sand is placed between the silica flour and bentonite to assist in keeping the bentonite from working into the silica flour surrounding the HDU.

5. $20 \mathrm{~cm}$ of sand is added followed by $20 \mathrm{~cm}$ of silica flour within which is the HDU and again $20 \mathrm{~cm}$ more of sand.

6. Depending on whether two or four HDUs are installed in a single borehole, this sequence is repeated. 
7. The borehole is completed to the surface with bentonite. A casing and cap are installed flush with the surface to protect instrument wiring.
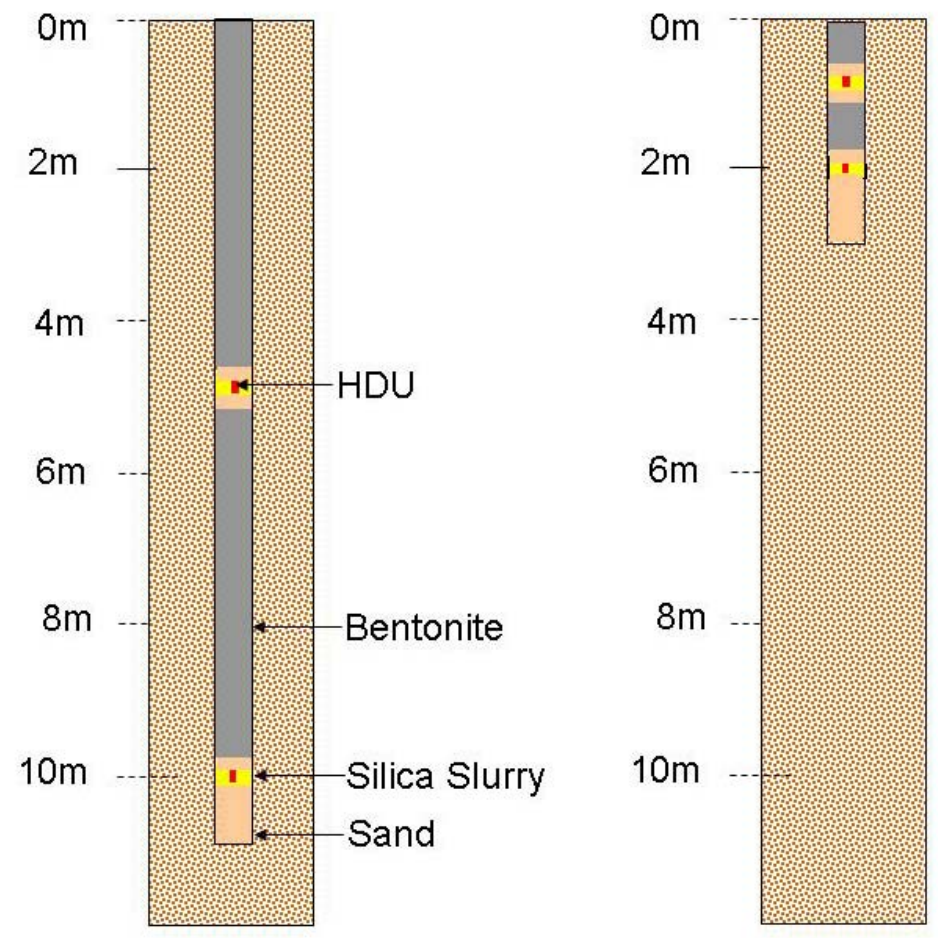

Figure 3.6. HDU Installation and Packing Material Layering Scheme

\section{Drain Gauge}

Procedures of drain gauge installation are described below:

1. Auger a hole large enough in diameter to accommodate the 8-inch-OD DCT. The depth of this hole will be the length of the DCT, or $0.67 \mathrm{~m}$ (2.2 feet). The sediment removed from the hole while auguring is to be set aside to be used later to pack the divergence control tube. A casing will be placed in the augered hole to preserve the hole during installation.

2. After auguring to the correct depth, a 3-inch-diameter hole will be pushed to a depth of $1.2 \mathrm{~m} \mathrm{(4 \textrm {ft } )}$ past the base of the large-diameter auger hole. The drive shaft is removed, and if the hole does not remain stable, the drive shaft is again driven into the hole until the hole maintains its structure after removing the drive shaft.

3. Once the drive shaft is removed, a manufacturer-supplied 3-inch-OD, 4-foot-long PVC tube is inserted into the push hole. The top of the PVC pipe should sit flush with the bottom of the DCT hole.

4. 12 inches of gravel is poured into the PVC tube to allow for unabated movement of the drainage away from the drain gauge when it doses.

5. The wick section of the drain gauge is placed inside the PVC tube with the top plate resting on the bottom of the DCT hole. The gauge wiring and calibration line will run out of the PVC tube through a notch in the top of the tube.

6. A 2-cm-thick layer of manufacturer-provided diatomaceous earth is placed on top of the fiberglass fabric to enhance contact between the soil in the DCT and the fiberglass wick. 
7. Set the DCT on top of the plate.

8. Repack the soil removed from the DCT hole. Care should be taken to repack the soil layers in the same order in which they were removed and at approximately the same density as the surrounding soil.

9. Backfill and pack the soil around the DCT and finish the installation by bringing the soil surface above the drain gauge level with the surrounding surface. The steel casing placed in the DCT hole during installation will remain in the ground to provide a level of added protection to the instrument.

\section{Meteorological Station}

The meteorological station will be set up following manufacturer's instructions. The station will be wired to the datalogger for automated measurements.

\section{Datalogger and Wiring}

All wiring from instruments within the tank farm will connect to a single cableway running north to the datalogger outside of the tank farm. To protect the wiring from vehicle and foot traffic as well as prevent damage caused by animals, the wiring will be run through enclosed tubing that is buried to a shallow depth $(<1 \mathrm{ft})$. The tubing is to terminate at the datalogger box where it is securely connected to the box. The datalogger will be installed in a weather box containing desiccant to keep precipitation and moisture away from the datalogger. The weather box will be installed above the ground by attaching it to a vertical metal stake securely placed in the ground.

\subsubsection{Instrument Calibration}

\section{Neutron Moisture Probe}

Because the neutron moisture probe to be used for this monitoring effort belongs to CHG and is in their possession, calibration will be CHG's responsibility. To date, the neutron probe has been calibrated using the 6-inch and 8-inch-diameter steel access tubes at the calibration facility near the Hanford Meteorological station. These calibrations will not be directly relatable to neutron probe measurements taken in the 2.5-inch OD access tubes to be installed in T tank farm and will introduce errors into the measurement. It is suggested that a calibration be developed for the neutron probe in a system using a 1.75 ID, 2.5 OD steel casing. One possible method of calibration is to use the computer code Monte Carlo Neutral Particles (MCNP) (Briesmeister 1993). Goncalves et al. (1992) has successfully demonstrated the calibration of neutron moisture probes using MCNP. The neutron probe measurements taken in the 6-inch and 8-inch-diameter access tubes at the calibration facility are compared to MCNP simulation results to confirm model accuracy and correct probe conceptualization. After this is achieved, MCNP simulations are initiated as before, but the 6 inch and 8 inch diameter access tubes are replaced with access tubes representing the size and composition of the access tubes to be installed in this plan. Results from these simulations are used to develop the neutron moisture probe calibration curve. A second method is to create calibration standards in a cylinder (e.g., 55-gallon drum) containing material of known moisture content or hydrogen content and the access tube to be used in the cover monitoring.

\section{EnviroSMART Capacitance Probe}

The capacitance probe will be calibrated using a normalization container available from CSI. The container is essentially a large plastic box with an EnviroSMART PVC access tube running down the middle of the box. The container will be packed with soil of known moisture content and measurements made with the EnviroSMART probe inserted inside the access tube. No less than three moisture contents will be used to develop a calibration curve relating probe output to moisture content. 


\section{Heat Dissipation Units}

The HDUs will be calibrated in the laboratory across the full range of expected field soil water pressures. Calibration at water pressures greater than -0.2 bar will be performed using a tension table or the hanging water column method of Dane and Hopmans (2002). At water pressures less than -0.2 bar, the units will be calibrated in a pressure-plate apparatus following the methods described by Reece (1996).

Drain Gauge

The manufacturer will calibrate the drain gauge. No field calibration will be required.

\section{Meteorological Station}

The manufacturer will calibrate the meteorological station. No field calibration will be required. 


\subsection{Quality Assurance}

To verify the quality of the project, a stand-alone project management plan (PMP) was prepared and approved by the product line manager. A quality assurance plan (QAP) was prepared by a quality specialist, who provides quality assurance support for the project. All the project members were required to follow the PMP and QAP. 


\subsection{References}

Atlantic-Richfield Hanford Company (ARHCO). 1973. 241-T-106 Tank leak investigation. ARH_2874, Atlantic-Richfield Hanford Company, Richland, WA.

Briesmeister JF. 1993. MCNP-A General Monte Carlo Code for Neutron Transport, Version 4A. LA 12625-M, Los Alamos National Laboratory, Los Alamos, NM.

Campbell Scientific, Inc. (CSI). 2002. Rain Gauges Models TE525WS, TE525, TE525MM, (brochure). Logan, UT.

Campbell Scientific, Inc. (CSI). 2006a. EnviroSMART Soil Water Content Profile Probes - Instruction Manual. Logan, UT.

Campbell Scientific, Inc. (CSI). 2006b. "Soil Volumetric Water Content/Salinity Probes Models EasyAG II and EnviroSMART,” (brochure). Logan, UT.

Campbell Scientific, Inc. (CSI). 2006c. “Temperature Probes Models 107 and 108,” (brochure). Logan, UT.

Dane JH and JW Hopmans. 2002. "Water Retention and Storage.” In: J Dane and C Topp (eds.), Ch 2, pp. 671-717, Methods of Soil Analysis, Part 4. Physical Methods. Book Series 5, Soil Sci. Soc. Am., Madison, Wisconsin.

Decagon. 2003. “Gee Passive Capillary Lysimeter,” (brochure). Pullman, WA.

Everett, LG, LG Wilson, and EW Hoylman. 1984. Vadose Zone Monitoring for Hazardous Waste Sites. Noyes Data Corporation, Parkridge, NJ.

Evett SR. 2001. "Exploits and Endeavors in Soil Water Management and Conservation Using Nuclear Techniques.” In: Proc. International Symposium on Nuclear Techniques in Integrated Plan Nutrient, Water and Soil Management. Vienna, Austria, 16-20 October 2000. International Atomic Energy Agency, Vienna Austria.

Gee, GW, JM Keller, and AL Ward. 2005. "Measurement and Prediction of Deep Drainage from Bare Sediments at a Semiarid Site.” Vadose Zone Journal 4:32-40.

Goncalves IF, J Salgado, and FG Carvalho. 1992. "Calibration of a Neutron Moisture Gauge by MonteCarlo Simulation.” Nuclear Geophysics 6(3):371-381.

International Atomic Energy Agency (IAEA). 1970. Neutron moisture gauges. Tech. Rep. Ser. No. 112, Vienna, Austria. 
Khaleel R, FJ Anderson, MP Connelly, TE Jones, FM Mann, DA Myers, and MI Wood. 2004. Modeling data package for WMAs $T$ and TX-TY Field Investigation report. RPP-17393 Rev. 0, CH2MHiLL Hanford Group, Inc., Richland, WA.

Myers DA. 2005. Field Investigation Report for Waste Management Areas. RPR-23752, CH2M Hill Hanford Group, Richland, WA.

Reece C. 1996. "Evaluation of line heat dissipation sensor for measuring soil matric potential.” Soil Sci. Soc. Am. J. 60:1022-1028.

Routson RC, WH Price, DJ Brown, and KR Fecht. 1979. High-level waste leakage from the 241-T-106 tank at Hanford. RHO-ST-14, Rockwell Hanford Operations, Richland, WA.

Serne RJ, BN Bjornstad, DG Horton, DC Lanigan, HT Schaef, CW Lindenmeier, MJ Lindberg, RE Clayton, VL LeGore, KN Geiszler, SR Baum, MM Valenta, IV Kutnyakov, TS Vickerman, RD Orr, CF Brown. 2004. Characterization of Vadose Zone Sediments Below the T Tank Farm: Boreholes C4104, C4105, 299-W10-196, and RCRA Borehole 299-W11-39. PNNL-14849, Pacific Northwest National Laboratory, Richland WA.

U.S. Department of Energy (DOE). 2005. Hanford Tank Farms Vadose Zone Monitoring Project, Annual Monitoring Report for Fiscal Year 2004. DOE-EM/GJ777-2004, Grand Junction Office, Grand Junction, CO.

van Genuchten MTh. 1980. "A closed-form equation for predicting the hydraulic conductivity of unsaturated soils.” Soil Science Society of America Journal 44:892-898.

Ward AL, TC Caldwell, and GW Gee. 2000. Vadose Zone Transport Field Study: Soil Water Content Distribution by Neutron Moderation. PNNL-13795, Pacific Northwest National Laboratory, Richland, WA.

White MD, and M Oostrom. 2004. User's guide of STOMP - Subsurface transport over multiple phases, Version 3.1. PNNL-14478, Pacific Northwest National Laboratory, Richland, WA. 
Appendix A

\section{EnviroSMART Probe Installation Procedure}





\section{Appendix A: EnviroSMART Probe Installation Procedure}

This information is adapted from Appendix C of the EnviroSMART instruction manual (Campbell Scientific, Inc., 2006).

\section{A.1 Cleaning the Access Tube}

The access tube must be cleaned before the top cap and bottom stopper are installed and readings are taken. To clean the access tube:

1. Attach foam to a length of rod and plunge the foam up and down the length of the access tube.

2. Attach a clean cotton cloth to a length of rod and saturate with denatured alcohol. Move this cloth up and down the access tube to clean off the final dirt residue from the access tube.

3. After cleaning the tube, use a flashlight to inspect the inside of the access tube. You should be able to see clean walls and the lip of the cutting edge at the bottom.

\section{A.2 Installing the Bottom Stopper Bung}

The bottom stopper bung is installed after the access tube has been cleaned. To install the bung:

1. Verify that the access tube is clean.

2. Partially insert the bung into the access tube and hold it at the upper end so $75 \%$ of the top rubber ring is within the access tube.

3. Tighten the wing nut to the point where there is enough friction on the wall of the access tube to prevent the bung from turning in the tube while the wing nut is tightened.

4. Place the bung tightening tool over the wing nut and slowly push the bung down the access tube. Allow air to escape until the bung rests on top of the internal cutting edge of the inside of the tube.

5. Slowly turn the bung tightening tool until you feel resistance to turning when the bung is sitting tight.

\section{A.3 Installing the Top Cap}

The top cap assembly is installed after the access tube has been cleaned and the bottom stopper fitted. To install the top cap assembly, follow these steps:

1. Verify that the top $4 \mathrm{~cm}$ of the access tube is clean on the inside and the outside.

2. With a silicon gun, apply three rings of silicon around the outside of the access tube about $1 \mathrm{~cm}$ below the top rim of the tube.

3. Unscrew the cap from the top cap assembly base.

4. Take the top cap base and push it onto the top of the access tube with a slight forward and backward rotating motion until the bottom foot of the top cap touches the undisturbed soil surface.

5. Wipe off excess silicon from the inside of the access tube.

6. Screw the cap back onto the top cap housing. 


\section{A.4 References}

Campbell Scientific, Inc. 2006. EnviroSMART Soil Water Content Profile Probes - Instruction Manual. Logan, UT. 


\section{Distribution List}

No. of

Copies

ONSITE

$6 \quad$ CH2M-HILL Group, Inc.

F.J. Anderson (2) E6-35

F.M. Mann E6-35

D.A. Myers E6-35

N.L. Peters E6-35

H.A. Sydnor E6-35

$1 \quad$ Energy Solutions

K.D. Reynolds H1-11

10 Pacific Northwest National Laboratory

Z.F. Zhang (2) K9-36

J.M. Keller BPO

E.J. Freeman K9-36

M.J. Fayer K9-36

G.W. Gee K9-36

R.R. Kirkham K9-36

A.L Ward K9-36

Information Release (2) P8-55

Distr. 1 